\title{
Cleavage of plasma membrane calcium pumps by caspases: a link between apoptosis and necrosis
}

\author{
BL Schwab ${ }^{1}$, D Guerini ${ }^{2}$, C Didszun ${ }^{1,5}$, D Bano ${ }^{4}$, \\ E Ferrando-May ${ }^{1}$, E Fava ${ }^{1,5}$, J Tam ${ }^{3}$, D Xu ${ }^{3}$, S Xanthoudakis ${ }^{3}$, \\ DW Nicholson ${ }^{3}$, E Carafoli $^{4}$ and $P$ Nicotera ${ }^{\star, 1,5}$ \\ ${ }^{1}$ Molecular Toxicology, Faculty of Biology, University of Konstanz, Germany \\ 2 Department of Metabolic and Cardiovascular Diseases, Novartis \\ Pharmaceuticals, 4002 Basel, Switzerland \\ 3 Pharmacology, Biochemistry and Molecular Biology Merck Frosst Centre for \\ Therapeutic Research, Dorval, Quebec, Canada \\ ${ }^{4}$ Department of Biochemistry and Venetian Institute of Molecular Medicine, \\ University of Padova, Italy \\ ${ }^{5}$ MRC Toxicology Unit, Hodgkin Building University of Leicester, Lancaster \\ Road, LE1 9HN Leicester, UK \\ * Corresponding author: P Nicotera, MRC Toxicology Unit, Hodgkin Building, \\ University of Leicester, Lancaster Road, LE $19 H N$ Leicester, UK. \\ Tel: +44(0)116 2525611; Fax: +44(0)116 2525599; E-mail: pn10@le.ac.uk
}

Received 29.1.02; accepted 30.1.02

Edited by G Melino

\begin{abstract}
Neuronal death, which follows ischemic injury or is triggered by excitotoxins, can occur by both apoptosis and necrosis. Caspases, which are not directly required for necrotic cell death, are central mediators of the apoptotic program. Here we demonstrate that caspases cleave and inactivate the plasma membrane $\mathrm{Ca}^{2+}$ pump (PMCA) in neurons and non-neuronal cells undergoing apoptosis. PMCA cleavage impairs intracellular $\mathrm{Ca}^{2+}$ handling, which results in $\mathrm{Ca}^{2+}$ overload. Expression of non-cleavable PMCA mutants prevents the disturbance in $\mathrm{Ca}^{2+}$ handling, slows down the kinetics of apoptosis, and markedly delays secondary cell lysis (necrosis). These findings suggest that caspase-mediated cleavage and inactivation of PMCAs can lead to necrosis, an event that is reduced by caspase inhibitors in brain ischemia. Cell Death and Differentiation (2002) 9, 818-831. doi:10.1038/ sj.cdd. 4401042
\end{abstract}

Keywords: apoptosis; brain ischemia; calcium; caspases

Abbreviations: PMCA, plasma membrane calcium; ATPase hPMCA4, human plasma membrane calcium ATPase isoform 4; CGN, cerebellar granule neurons; GSNO, S-nitrosoglutathione; NMDA, N-methyl-D-aspartate; MK-801, 5-methyl-10,11-dihydro$5 \mathrm{H}$-dibenzo [a,d] cycloheptene-5,10-imine hydrogen maleate; AcYVAD-cho, Ac-Tyr-Val-Ala-Asp-chloromethylketone; Sf9, Spodoptera frugiperda; STS, staurosporine; Z-VAD-fmk, Z-Val-Ala-DLAsp(OMe)-fluoromethylketone; NCX, sodium/calcium-exchanger

\section{Introduction}

The apoptotic death program seems to converge mainly on one class of proteases, the caspases (cysteine aspartases), which can execute death signals in virtually every cell (see ${ }^{1,2}$ for reviews). Based on their substrate specificity, the caspase gene family can be subdivided into three major groups: group I caspases-1, $-4,-5,-13$ are predominantly involved in cytokine processing and therefore in inflammatory processes; group II caspases-2, -3, -7) are considered the major effectors of death signals (execution caspases); group III caspases-6, $-8,-9,-10$ are upstream activators of the group II caspases. Recent work indicates that the murine caspase-11, which shares homology with human caspase-4, can also activate caspase- 1 and caspase- 3 . $^{3}$ Many of the caspase substrates are responsible for the appearance of the characteristic apoptotic features (i.e., DNA laddering, nuclear envelope breakdown, cell shrinkage and exposure of phosphatidylserines). Whereas inhibition of effector caspases prevents the appearance of the apoptotic morphology in most cases, it does not always preclude the occurrence of cell death that may be triggered by other programmes/pathways. ${ }^{4,5}$

With the notable exception of group III caspases, which are linked to death domains, ${ }^{6}$ and act upstream of the processes involved in both apoptosis and necrosis, ${ }^{7}$ this family of proteases does not apparently execute death forms other than apoptosis. Nevertheless, caspase inhibition reduces the overall rate of cell death in ischemic stroke models ${ }^{8-10}$ where the necrotic morphology is predominant. ${ }^{11,12}$ Reduction of caspase-dependent pro-inflammatory reactions ${ }^{13-15}$ or involvement of death receptors and group III caspases ${ }^{16,17}$ may partly explain the global protective effect (i.e., prevention of both apoptosis and necrosis) of broad-spectrum caspase inhibitors in vivo. A yet more selective inhibition of either group II or group I caspases shows intriguing differences: caspase-1 inhibition by YVAD.cmk reduces both the size of brain infarcts and brain swelling, whereas inhibition of caspase-3 by DEVDfmk reduces brain infarcts, but not swelling after middle cerebral artery occlusion. ${ }^{13}$ These observations, along with experiments using different, more selective strategies to inhibit caspase $-3^{10}$, suggest that inhibitors of group II caspases can protect against both apoptosis and necrosis in stroke models. Caspase inhibition can stave-off the breakdown of the cell membrane, which follows the execution of other typical degradative processes of apoptosis. Eventually, cells can lyse even after the apoptotic morphology has been accomplished, and a necrotic phenotype may ensue if scavenging of dying cells is insufficient. This secondary necrosis has been observed after liver injury ${ }^{18}$ and is common in in vitro models of apoptosis. The signals leading to secondary lysis or necrosis are unknown. Osmotic imbalance intervening in doomed cells may lead to cell rupture. Such an ionic imbalance may result from gain and/or loss of function in ion channels and exchangers brought about by protease activation. Previous studies in neurons have shown that 
$\mathrm{Ca}^{2+}$-permeable glutamate receptors of the AMPA-subtype can be cleaved by caspases. ${ }^{19}$ Their inactivation would avoid excitotoxicity and $\mathrm{Ca}^{2+}$ overload in neurons destined to apoptose. ${ }^{20}$ While cleavage of AMPA channels and loss of $\mathrm{Ca}^{2+}$ conductance may prevent the lethal effects of $\mathrm{Ca}^{2+}$ overload and a potential switch from apoptosis to necrosis, inhibition of cellular $\mathrm{Ca}^{2+}$ efflux would ensue in $\mathrm{Ca}^{2+}$ overload and cell death. ${ }^{21}$ Intracellular $\mathrm{Ca}^{2+}$ overload can set off cell demise via $\mathrm{Ca}^{2+}$-dependent processes ${ }^{22}$, change the balance of neuronal death from apoptosis to necrosis by depleting energy stores, ${ }^{23}$ or augment other death execution mechanisms. For instance, $\mathrm{Ca}^{2+}$-binding proteins e.g. calcineurin, can mobilize pro-apoptotic proteins to mitochondria, ${ }^{24}$ and the interplay between $\mathrm{Ca}^{2+}$. activated proteases and caspases may amplify apoptotic signals. ${ }^{25}$ Since the integrity of plasma membrane $\mathrm{Ca}^{2+}$ ATPase (PMCA) is essential to rectify changes in intracellular $\mathrm{Ca}^{2+}$ in the long-term, we decided to investigate the fate of calcium translocases in cells undergoing apoptosis. Independent genes encode the four major PMCA isoforms currently known. Another $\mathrm{Ca}^{2+}$ pump is located in the endo-/sarcoplasmic reticulum (SERCA). PMCA isoforms 1 and 4 are expressed ubiquitously in mammalian cells, whereas isoforms 2 and 3 are expressed in significant amounts only in the brain. ${ }^{26}$

In this study, we demonstrate that both the neuron specific PMCA2 and the ubiquitous PMCA4 isoforms are cleaved by caspases. PMCA2 is cleaved in vivo following brain ischemia and in neurons undergoing apoptosis after excitotoxic stimulation. PMCA4 is cleaved in non-neuronal cells induced to apoptose by staurosporine. Cleavage of PMCAs results in loss of function and aberrant intracellular $\mathrm{Ca}^{2+}$ transients. Expression of mutants of human PMCA4 that lack the caspase cleavage site(s) prevents $\mathrm{Ca}^{2+}$ overload during apoptosis and markedly delays secondary cell lysis/necrosis. These findings provide a possible explanation for the observation that caspase inhibitors prevent the appearance of secondary necrosis in stroke models, and rescue ischemic areas.

\section{Results \\ Cleavage of PMCA2 in brain ischemia and in excitotoxin-induced apoptosis}

At variance with the other neuronal isoform PMCA3, PMCA2 is reasonably well characterized. It participates in the neuronal developmental program and fully differentiated neurons express it in high amounts. ${ }^{26}$ To investigate the fate of PMCA2 during brain ischemia, neonatal $\mathrm{P} 7$ rats received left common carotid artery ligation and were exposed to $8 \%$ oxygen $/ 92 \%$ nitrogen for $2.5 \mathrm{~h}$. Western blot of lysates obtained from cortical samples showed that PMCA2 (133 kDa) was degraded to a main fragment of $123 \mathrm{kDa}$ (Figure 1). The extent of pump cleavage was related to the degree of brain injury as assessed by brain swelling and to the apoptotic index, which reflects apoptotic DNA fragmentation.

Neonatal hypoxia-ischemia is characterized by the presence of apoptotic features and the activation of the caspase execution machinery. ${ }^{27}$ To investigate whether PMCA2 was cleaved during excitoxin-induced apoptosis, CGN were exposed to either low concentrations of the direct excitotoxin glutamate, or to the indirect excitotoxins, S-nitrosoglutathione (GSNO) or 1-methyl-4-phenylpyridinium $\left(\mathrm{MPP}^{+}\right)$, which stimulate synaptic glutamate release and excitotoxicity. ${ }^{28,29}$ Western blots of membrane fractions isolated from CGN undergoing apoptosis, showed that PMCA2 (133 kDa) was degraded to the same $123 \mathrm{kDa}$ fragment found in the ischemic brain tissue (Figure 2A). Neurons pre-treated with the NMDA (N-methyl-D-aspartate)-receptor blocker, MK-801 (5-methyl-10, 11-dihydro$5 \mathrm{H}$-dibenzo [a, d] cycloheptene-5, 10-imine hydrogen
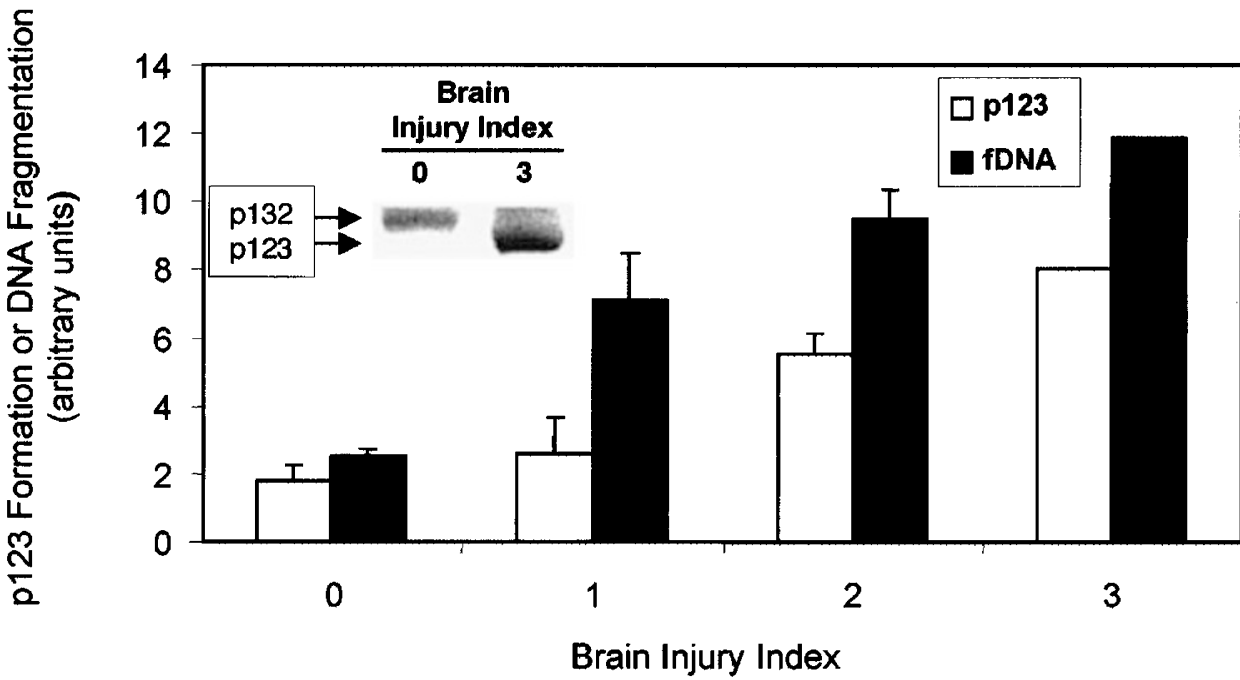

Figure 1 Cleavage of PCMA2 in brain ischemia. Neonatal P7 Sprague-Dawley rats underwent hypoxic injury as described in Materials and Methods. Brains were removed and scored for degree of injury (Brain Injury Index) and the extent of PCMA2 cleavage (p123) and apoptotic DNA fragmentation (fDNA) were assessed in the ipsilateral cortices. Data are the average \pm S.E. except $(n=13)$ for columns 3 where $n=1$. A representative Western blot of PCMA cleavage, comparing injury extremes (0 versus 3 ), is shown as an inset 
maleate), which prevents cell death in this model, also prevented PMCA2 cleavage. Similarly, the pan-caspase inhibitors z-D-cbk and Ac-YVAD-cho blocked PMCA2 cleavage (Figure 2B). Both caspase inhibitors prevented
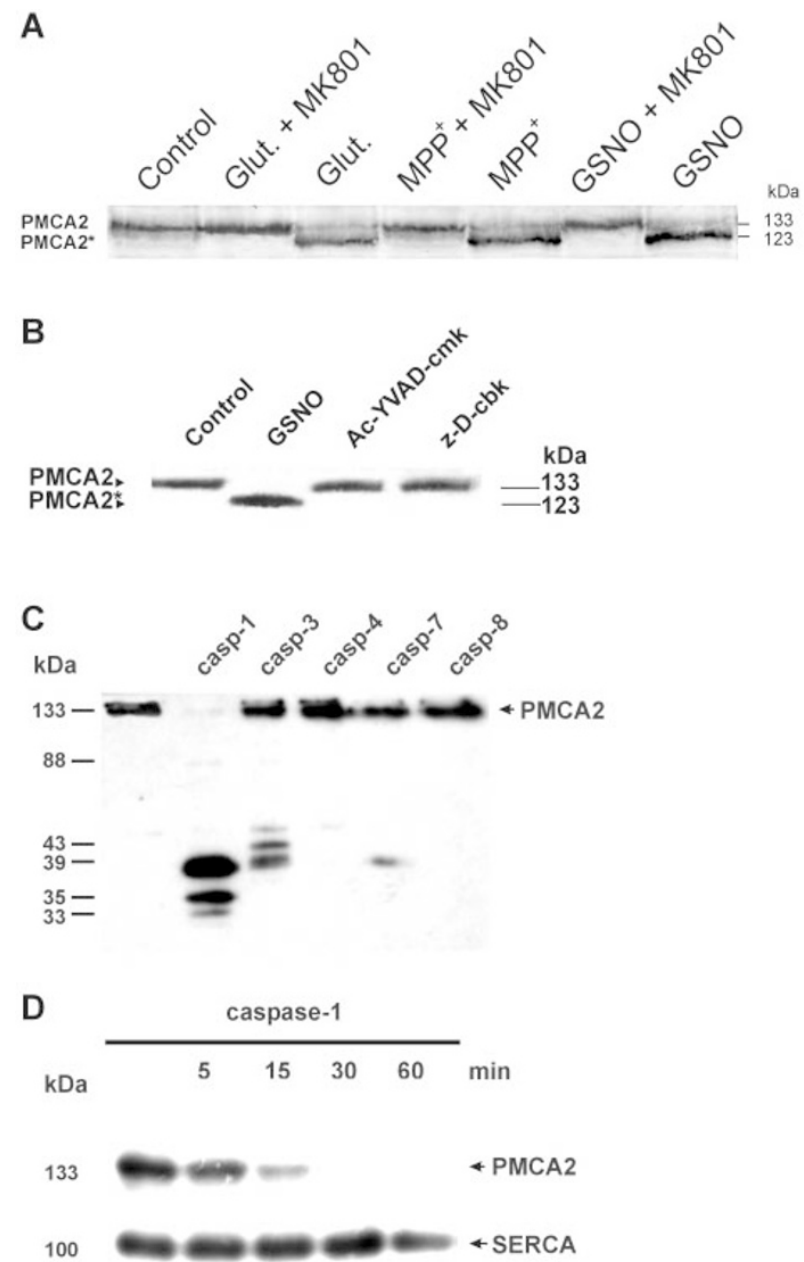

Figure 2 Cleavage and inactivation of PMCA2. (A) Cleavage of PMCA 2 was examined in CGN undergoing apoptosis after exposure to glutamate (Glut; $60 \mu \mathrm{M}), \mathrm{MPP}^{+}(50 \mu \mathrm{M})$, or GSNO $(300 \mu \mathrm{M})$. When nuclear condensation became noticeable by light microscopy (glutamate and $\mathrm{MPP}^{+}$after $2.5 \mathrm{~h}$, GSNO after $3.5 \mathrm{~h}$ ), neurons were lysed and the membrane enriched fraction run on SDS gels and subjected to Western blotting. In the experiments with MK-801, cells were pre-incubated with $2 \mu \mathrm{M}$ of the NMDA-channel blocker, for $30 \mathrm{~min}$ prior to the addition of the excitotoxins. (B) CGN were incubated for 30 min with the caspase-inhibitors Ac-YVAD-cmk or Z-D-cbk $(100 \mu \mathrm{M})$ before treatment with $300 \mu \mathrm{M}$ GSNO. In some experiments, z-VAD-fmk was used to inhibit caspases with results identical to those obtained with the other inhibitors (data not shown). (C) Proteins derived from membrane fractions of Sf9 cells that express hPMCA2 and the SERCA were incubated with caspase buffer (outer left lane) or with caspase-1, $-3,-4,-7$ or -8 for 30 min at $37^{\circ} \mathrm{C}$. (D) The effect of caspase-1 on PMCA2 activity was assessed by the formation of the intermediate phosphorylated enzyme from ATP. Sf9 membranes (25$50 \mu \mathrm{g}$ ) were phosphorylated under conditions promoting the formation of a phosphorylated intermediate from ATP in the presence of calcium and lanthanum. The figure shows the autoradiography of acidic gels after drying. Membranes were treated with caspase- 1 and aliquots corresponding to $1.2 \mu \mathrm{g}$ of membrane proteins were removed after $5,15,30$ and $60 \mathrm{~min}$. Whereas, PMCA2 was fully inactivated after $15 \mathrm{~min}$ of incubation with caspase-1 the SERCA retained its activity. In additional experiments, other caspases were ineffective in cleaving and inactivating the SERCA in SF9 membranes and in cells undergoing apoptosis (data not shown) neuronal apoptosis elicited by indirect excitotoxicity in CGN. ${ }^{29,30}$

To further investigate the cleavage of PMCA2, the plasma membrane enriched fraction was isolated from a clone of insect Sf9 cells that stably expresses human (h)PMCA2. We opted for the membrane preparation as opposed to the purified pump to study the pump in its regularly inserted and folded state. Membranes were exposed to caspases at $37^{\circ} \mathrm{C}$ for $1 \mathrm{~h}$. The pump (molecular mass about $133 \mathrm{kDa}$ ) was cleaved by caspase-1, by caspase- 3 and, to a lesser extent, by caspase-7 (Figure $2 \mathrm{C})$. The cleavage of the pump by caspase- 1 yielded a major fragment of about $40 \mathrm{kDa}$ and two less abundant fragments of about 35 and $33 \mathrm{kDa}$. Caspase- 3 produced fragments ranging in size between 40 and $43 \mathrm{kDa}$, whereas caspase-7 yielded only a minor fragment of about $40 \mathrm{kDa}$. Other caspases (i.e., 4 and 8) were ineffective.

Calcium pumps are P-type ATPases, i.e., they form a phosphorylated intermediate during the reaction cycle, ${ }^{31}$ which is used to determine pump activity. The phosphoenzyme formation was measured in membrane fractions from Sf-9 cells incubated with purified caspase-1, in the presence of $\gamma^{32} \mathrm{P}$-labeled ATP. The phosphorylated band decreased already after $5 \mathrm{~min}$ of incubation, and became undetectable after $15 \mathrm{~min}$ (Figure 2D). Thus, the cleavage of PMCA2 by caspase-1 led to its inactivation. Since the membrane preparation used in these experiments also contained significant amounts of the SERCA, we tested whether the formation of the phosphorylated intermediate by the latter was also affected by caspases. Caspase-1 (as well as the other caspases tested above) did not cleave and/or inactivate the SERCA pump (Figure 2D).

\section{Cleavage and inactivation of PMCA4 in vitro and in cells undergoing apoptosis}

To examine whether the ubiquitous pump isoform was also a substrate for caspases, we initially isolated membrane fractions from Sf9 cells expressing hPMCA4. Caspase-3, and somewhat less effectively caspase-7, cleaved the $134 \mathrm{kDa}$ PMCA4 to a product of about $119 \mathrm{kDa}$. Interestingly, at variance with PMCA2, caspase-1 was ineffective (Figure 3A).

The effect of caspase cleavage on PMCA4 activity was explored as described for PMCA2 (Figure 3B). The global pump activity as expressed by the phosphorylated intermediate, decreased and was virtually lost after $30 \mathrm{~min}$ in the presence of purified caspase-3.

To investigate whether the pump was cleaved in apoptosis, we chose two independent $\mathrm{CHO}$ cell clones (925 and 10150) that stably overexpress hPMCA4. Both were exposed to $1 \mu \mathrm{M}$ staurosporine (STS), ${ }^{32}$ which elicited apoptosis in about $35-50 \%$ of the cells after $5 \mathrm{~h}$. Following caspase-3 activation (detected by DEVDase activity; not shown), membrane fractions were isolated from untreated cells, cells treated with STS, or cells treated with STS combined with the caspase inhibitor z-VAD-fmk; hPMCA4 was cleaved to the $119 \mathrm{kDa}$ fragment in STS-treated clones, but not in clones treated with STS+Z-VAD (Figure 3C). 

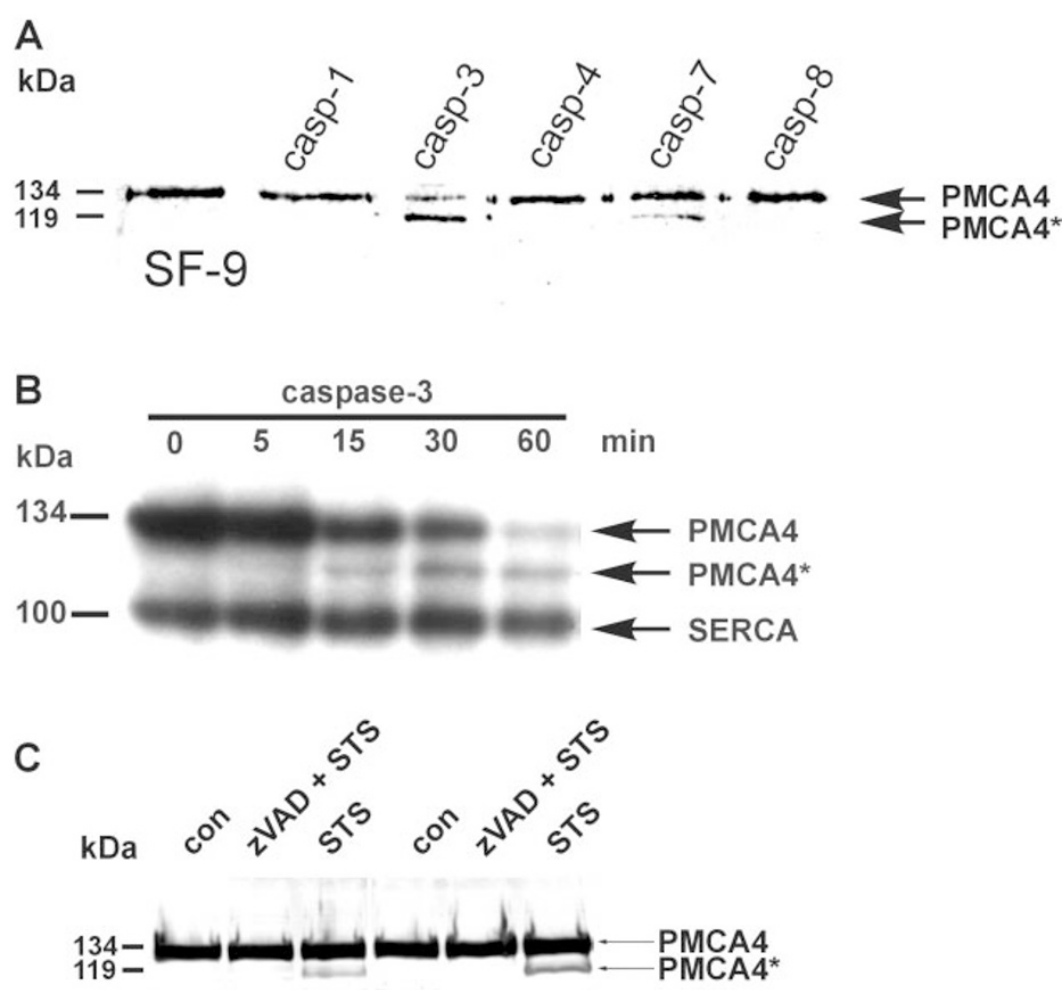

clone $925 \quad$ clone 10150

Figure 3 PMCA4 is cleaved and inactivated by caspase-3. (A) Proteins from Sf-9 membrane fractions containing hPMCA4 were incubated either with buffer alone (outer left lane) or with purified caspases-1, $-3,-4,-7$ or -8 as described for PMCA2. Samples were separated on SDS-gels, blotted on nitrocellulose, and probed with a polyclonal anti-hPMCA4 antibody. (B) The activity of hPMCA4 was measured after incubation with purified caspase-3 as described for hPMCA2 (see Figure 1). The main phosphorylated band corresponding to the intact pump decreased after 15 min and virtually disappeared after 30 min. Concomitantly, a phosphorylated band corresponding to the degradation product PMCA4* appeared in the autoradiography. Therefore, this fragment might have residual pump activity. However, since the pump is cleared from the plasma membrane after caspase cleavage (see Figure 5 ), it is highly unlikely that PMCA4* could pump Ca ${ }^{2+}$ outside the cell. (C) CHO cells overexpressing hPMCA4 were treated with staurosporine (STS). Two independent clones (925 and 10150) were triggered to apoptose by STS $(1 \mu \mathrm{M})$. Membrane fractions were isolated after $5 \mathrm{~h}$ and prepared for SDS-PAGE and immunoblotting. PMCA is cleaved to a $119 \mathrm{kDa}$ product $\left(\mathrm{PMCA}^{*}\right)$ recognized by an antibody raised against the pump N-terminal domain. Pre-treatment with the caspase inhibitor $z$-VAD-fmk abolished cleavage

\section{Identification of the caspase-3 cleavage site on PMCA4}

Next, we attempted to identify the caspase cleavage site on hPMCA4. The hPMCA4 was selected because of the availability of deletion mutants and antibodies that recognize specifically either the $\mathrm{N}$ - or the C-terminal domains of the protein. ${ }^{33}$ Crude membrane fractions were isolated from the clones 925 and 10150, as well as from a vector-transfected clone (4150) and wild-type $\mathrm{CHO}$ cells. Membranes were exposed to purified caspase-3 for $1 \mathrm{~h}$ at $37^{\circ} \mathrm{C}$. Since the antibody against hPMCA4 does not recognize the hamster PMCA4, no bands were detected in Western blots in the wt and vector-transfected clones (Figure 4A). Membrane fractions from the cell clones 925 and 10150, incubated with caspase-3, exhibited both the intact pump and its degradation product of $119 \mathrm{kDa}$, as in Sf-9/PMCA4 membrane fractions and in $\mathrm{CHO}$ cells undergoing apoptosis. The anti-PMCA4 antibody used in previous experiments recognizes a relatively small epitope in the $\mathrm{N}$-terminal portion of the pump. Since we did not detect small PMCA4 fragments after caspase cleavage in $\mathrm{CHO}$ cells, the cleavage site was evidently not located in the proximity of the N-terminus. In contrast, an antibody raised against the $\mathrm{C}$-terminal domain of the human PMCA4 recognized a fragment of about $25 \mathrm{kDa}$ (Figure 4B). The caspase-3 cleavage site on PMCA4 was further characterized by using deletion mutants with different C-terminal truncations. ${ }^{34}$ PMCA4 consists of 1205 amino acids. The $\Delta 44$ mutant lacks the 44 C-terminal residues, (from phenylalanine 1162 to valine 1205), whereas the $\Delta 139$ mutant lacks the $139 \mathrm{C}$-terminal residues (from glutamic acid 1067 to valine 1205). Both mutants were subjected to in vitro cleavage with purified caspase-3, using the full length PMCA4 as a control. While the $\Delta 44$ mutant was still cleaved, the $\Delta 139$ mutant was not (Figure $4 \mathrm{C}$ ), which suggested that the cleavage site was located between glutamic acid 1067 and phenylalanine 1162. In addition, the degradation band from the full-length PMCA4 was approximately $1 \mathrm{kDa}$ larger than the native band of the $\Delta 139$ mutant, restricting potential cleavage sites to the DEID sequence between D1077 and D1080. 

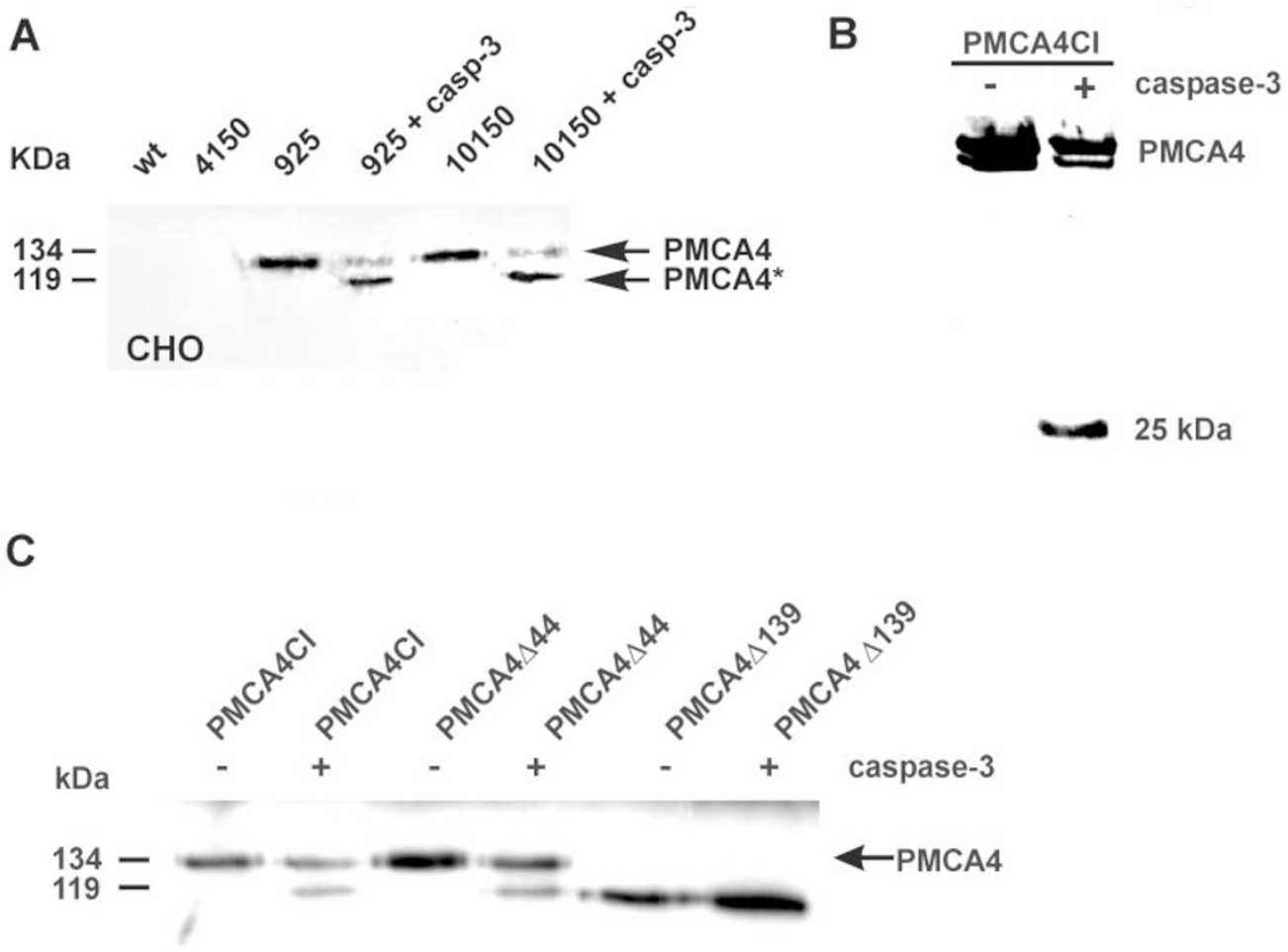

Figure 4 Identification of the cleavage site. To determine the cleavage site we examined $\mathrm{CHO}$ clones stably expressing full-length and truncated hPMCA4. (A) Membrane fractions prepared from four different $\mathrm{CHO}$ clones (wt: wild-type, 4150: vector-transfected, 925 and 10150 stably overexpressing hPMCA4) were subjected to in vitro cleavage with purified caspase- 3 for $1 \mathrm{~h}$ at $37^{\circ} \mathrm{C}$. The constitutive hamster PMCAs are not recognized by the human antibody. In the 925 and 10150 clones, the degradation band reveals the same size product PMCA4* as in Sf9 membranes and in $\mathrm{CHO}$ cells undergoing apoptosis. (B) Membrane fractions of Sf9 cells containing full length $(\mathrm{Cl})$ hPMCA4 were subjected to in vitro cleavage with purified caspase-3. The Western blot was stained with antibodies against the C-terminal part of the pump (p94.2). ${ }^{33}$ Caspase-3 generated a $25 \mathrm{kDa}$ (in SDS-PAGE) C-terminal fragment. The exact molecular mass could be slightly different, due to the very acidic character of the C-terminus of the pump, which may be responsible for an abnormal gel migration. (C) Proteins from membranes containing full-length hPMCA4 $(\mathrm{Cl})$ or two truncated forms $(\Delta 44$ and $\Delta 139)$ were subjected to in vitro cleavage with purified caspase-3. The $\Delta 44$ mutant lacks the 44 C-terminal residues stretch, from amino acids phenylalanine 1162 to valine 1205 . PMCA $\Delta 139$ lacks the amino acids glutamic acid 1067 to valine 1205 . (Note that the $\Delta 44$ mutant migrates at higher position than expected from its molecular weight, due to the acidic character of the mutant protein). The $\Delta 139$ mutant was not cleaved and migrated at $118 \mathrm{kDa}$

\section{Expression of PMCA4 mutants non-cleavable by caspases}

Both aspartic acid residues in the sequence $D_{1077} E I D_{1080}$ were mutated to alanine residues (see scheme in Figure 5A). $\mathrm{CHO}$ cells were then transfected with the mutant plasmids and clones were selected for expression of the D1080A (A) or D1077A (B) mutants. Membrane fractions were then analyzed by Western blotting. Both mutant clones reacted with an antibody that recognizes the full-length human PMCA4 (Figure 5B). $\mathrm{CHO}$ clones that stably overexpress wild-type hPMCA4 (clone 925) and human cells (HeLa) that constitutively express PMCA4 were used as controls. All cell clones were then stimulated with $1 \mu \mathrm{M}$ STS to undergo apoptosis. hPMCA4 was cleaved in the wild-type clone, in clone 925 and in HeLa cells, whereas no cleavage was detected in the two mutants. Incubation of the 925 clone or HeLa cells with the poly-caspase inhibitor z-VAD-fmk prevented pump cleavage. Intact PMCA4 was still detectable in the non-mutant clones treated with STS, possibly reflecting that a fraction of the population did not undergo apoptosis. We therefore examined the subcellular distribution of the wild-type pump, and the newly expressed mutants of PMCA4 in healthy and dying cells. Confocal images show that both the wild-type human PMCA4 and the mutants were correctly targeted to the plasma membrane (Figure 6A). Analysis of individual cells revealed that the wild-type hPMCA4 signal disappeared from the plasma membrane in virtually all cells undergoing apoptosis (after $5 \mathrm{~h}$ incubation with STS) (Figure 6B). The hPMCA signal was fully retained in the mutants treated with STS or in wild-type cells treated with STS plus the caspase inhibitor Z-VAD-fmk.

Cleavage of PMCA4 by caspases exposes a sequence that targets C-terminally-truncated pumps to the endoplasmic reticulum where they are retained and degraded. ${ }^{34}$ Endocytosis of membrane proteins is a frequent event following secretory activity ${ }^{35}$ and the unmasking of the PMCA sequence, which normally causes pump retention in the endoplasmic reticulum, might have promoted the internalization and subsequent degradation of the pump. Thus, we examined the subcellular localization of PMCA4 in comparison with that of the SERCA, which resides in the endoplasmic 

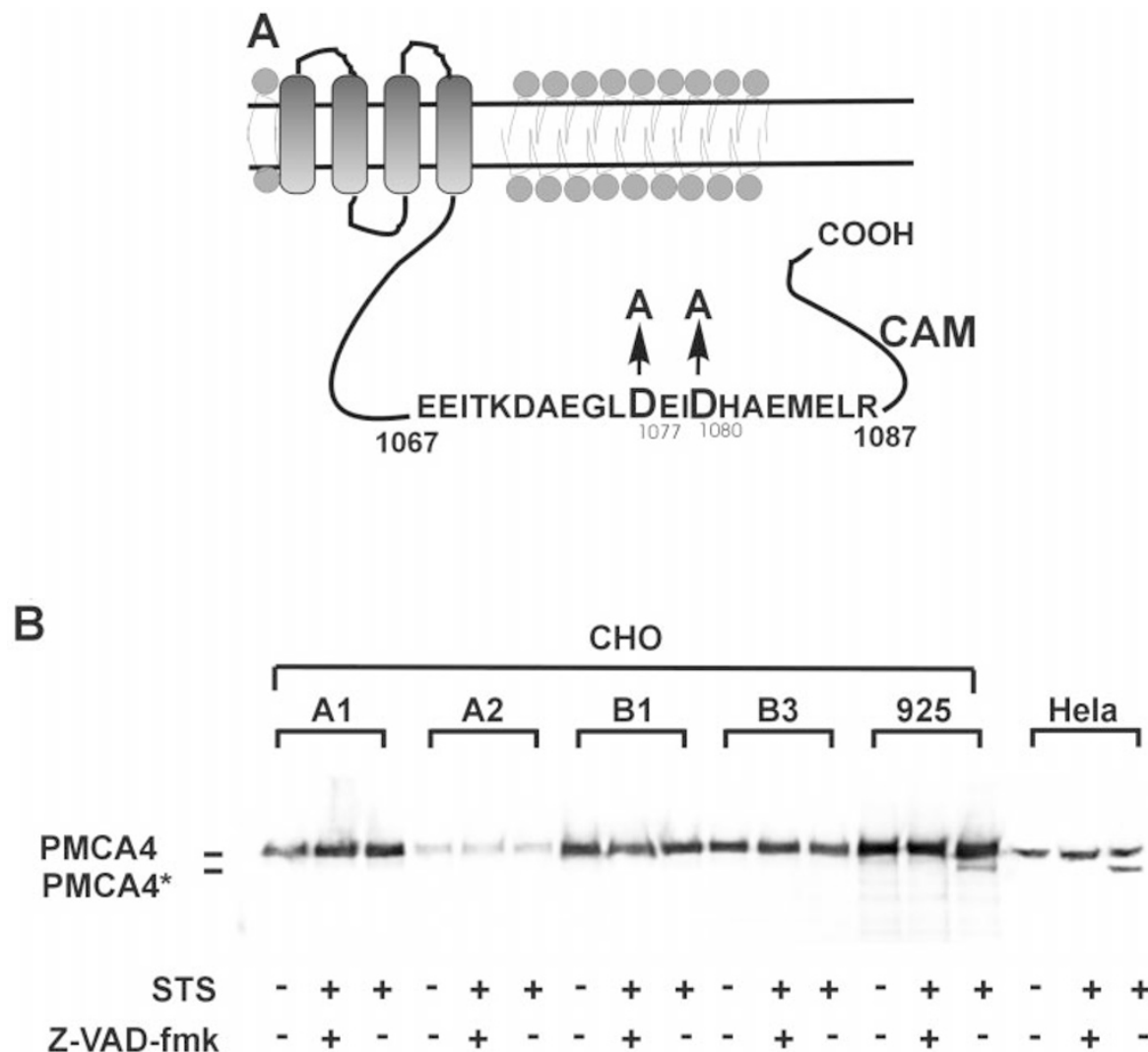

Figure 5 Mutation of the caspase cleavage site makes PMCA4 resistant to degradation in apoptosis. (A) Two sets of mutant clones were generated by substituting either D1080 (mutant A) or D1077 (mutant B) of the DEID sequence with alanine. The DEID sequence cleavable by caspase-3 is located upstream of the calmodulin (CAM)-binding site at the C-terminus of the pump. (B) Two stably transfected $\mathrm{CHO}$ clones expressing each of the mutations were selected and exposed to $1 \mu \mathrm{M}$ STS in the absence or presence of z-VAD-fmk. The 925 clones stably overexpressing the wt hPMCA4 and HeLa cells that constitutively express hPMCA4 were used as controls. After $5 \mathrm{~h}$ cells were harvested and the membrane fraction was isolated to determine PMCA4 cleavage. The pump was cleaved in the 925 clone and in HeLa cells. Pump cleavage was prevented by z-VAD-fmk. In clones A1, A2 or B1, B3, which express hPMCA4 mutants, the pump was not cleaved by caspases

reticulum and is not cleaved by caspases. Figure 7A shows control cells, in which the red fluorescence of the PMCA pump in the cell outer rim is well separated from the green fluorescence of the SERCA pump in the cell interior. Cells showing initial features of apoptosis were selected at a time when caspase activation was detectable ( $4-5 \mathrm{~h}$ after STS). As shown in the images in Figure 7, hPMCA4 appeared to colocalize with the SERCA pump in discrete sub-membrane regions (yellow spots in Figure 7B). In contrast, non-cleavable hPMCA4 remained localized on the plasma membrane, even in cells with condensed nuclei, while the SERCA stained the perinuclear region of cells undergoing apoptosis (Figure 7B,C,D and inset. Panel A shows the PMCA and SERCA distribution in untreated cells).

\section{Cleavage of hPMCA4 and $\mathrm{Ca}^{2+}$ handling in cells undergoing apoptosis}

To determine whether pump cleavage would compromise the ability of cells to cope with intracellular $\mathrm{Ca}^{2+}$ elevations, ionomycin-stimulated $\mathrm{Ca}^{2+}$ transients were measured in the clones 925 and 10150, the wild-type and the vector- transfected clones. Responses of untreated cells were compared to those after STS treatment. Changes in the free intracellular $\mathrm{Ca}^{2+}$ concentration $\left(\left[\mathrm{Ca}^{2+}\right]_{\mathrm{i}}\right)$ were also monitored prior to caspase activation and were generally identical to those of untreated cells (data not shown). In all clones, the ionophore, ionomycin caused an immediate increase of $\left[\mathrm{Ca}^{2+}\right]_{i}$. The wild-type clone and the vector-transfected cells began rectifying the $\mathrm{Ca}^{2+}$ increase after $5 \mathrm{~min}$ (traces $\mathrm{a}$, in Figure $8 \mathrm{~A}$ and $\mathrm{C}$ ). In cells overexpressing hPMCA4 the elevation of $\left[\mathrm{Ca}^{2+}\right]_{i}$ decayed more rapidly, i.e., $\left[\mathrm{Ca}^{2+}\right]_{i}$ returned to the basal level within approximately $45-60 \mathrm{~s}$ (trace a, in Figure 8B). In cells displaying initial features of apoptosis (i.e., nuclear ruffling and initial chromatin condensation), the ionomycin-induced $\left[\mathrm{Ca}^{2+}\right]_{i}$ increase was not rectified at all and remained at peak levels (traces $b$ in Figure $8 A-C$ ). When cells were exposed to STS in the presence of z-VAD-fmk to block caspase activation, the normal, ionomycin-evoked $\left[\mathrm{Ca}^{2+}\right]_{\mathrm{i}}$ response was recovered; i.e., returned to baseline with kinetics that resembled those of the corresponding untreated clones (compare traces $c$ with traces a in Figure $8 \mathrm{~A}-\mathrm{C}$ ).

Next, we examined $\mathrm{Ca}^{2+}$ handling in the mutant $\mathrm{CHO}$ clones. $\mathrm{Ca}^{2+}$ signals were again measured in untreated 
A clone 925
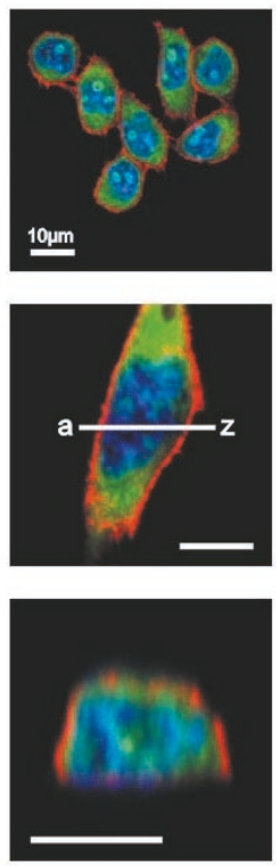

clone 925

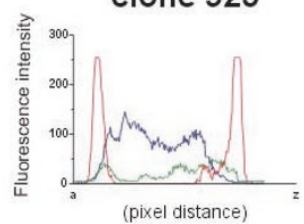

Mutant A
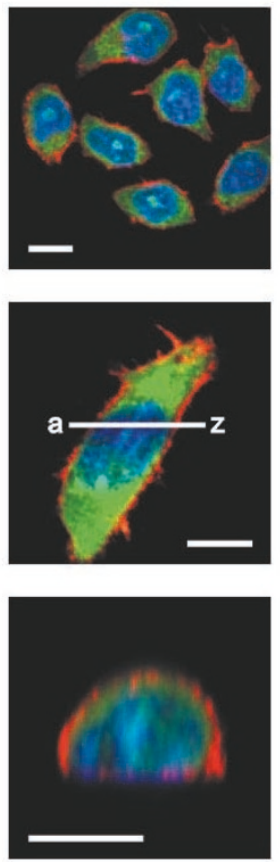

Mutant A

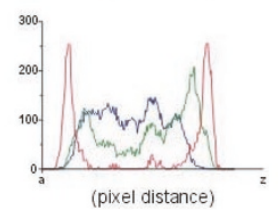

Mutant B
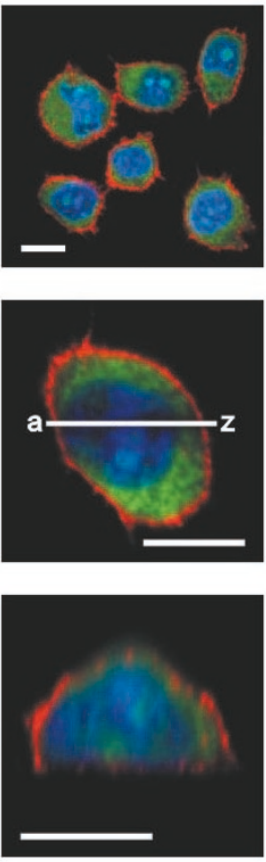

Mutant B

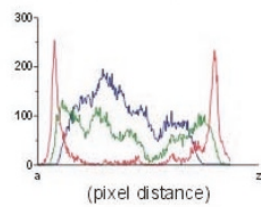

B
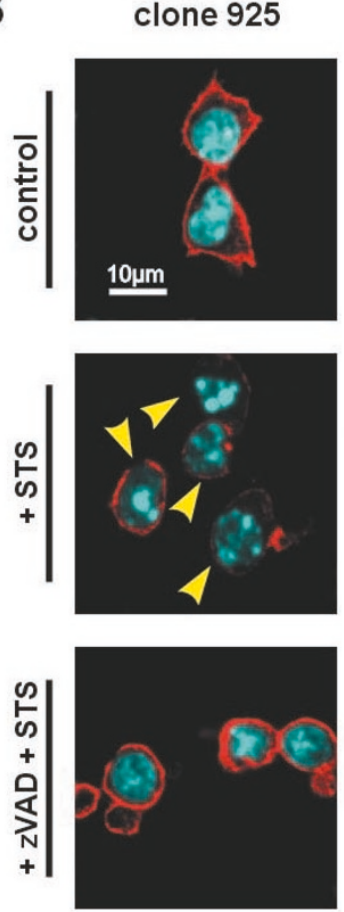

Mutant A
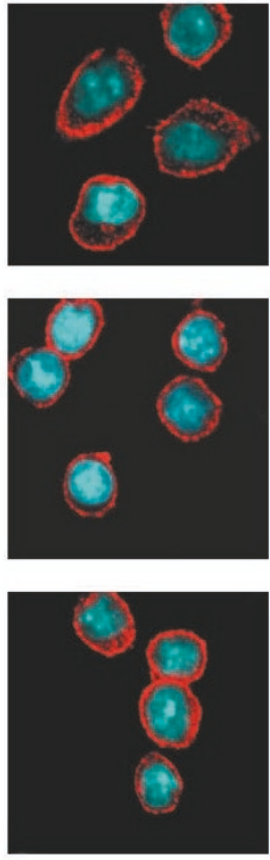

Figure 6 Subcellular localization of wt and mutant PMCA4 in stably transfected CHO cells. (A) Cells stably overexpressing the wt pump (clone 925) and two mutant clones (Mutants A and B), were fixed and stained with a mouse monoclonal antibody recognizing the large central cytoplasmic loop of hPMCA4 and a secondary goat Alexa ${ }^{(i m} 594$ antibody, which fluoresces red. The cytoplasm was stained with Cell-Tracker ${ }^{(i i)}$ CMFDA (green fluorescence) and nuclei were stained blue with Hoechst 33342. The localization of the pump was studied in the $x / y$ and $x / z$ focal planes by confocal microscopy. The pump appeared selectively localized on the cell membrane as also shown by the pixel analysis at the base of the figure. The single pixel line (a-z) crossing a randomly selected cell was scanned using the Leica Scanware software. Numerical intensity values along the line selection for each channel were exported in Excel ${ }^{(i x}$ (Microsoft, Co.) and profiles were drawn. The red line represents the localization of PMCA4, the green line shows Cell-Tracker ${ }^{(i i}$ and the blue line shows Hoechst 33342 as in the images. A total of 100 cells were imaged. Representative images are shown. All scale bars correspond to $10 \mu \mathrm{m}$. (B) Both the 925 clone and mutant clone A were exposed to STS or to STS plus z-VAD-fmk as described above. After $5 \mathrm{~h}$ cells were fixed and stained with the combination of Hoechst 33342 and hPMCA4 antibodies. PMCA disappeared from the 925 clone (indicated by arrows) undergoing apoptosis (as shown by chromatin fragmentation), but remained intact in individual cells expressing the mutant hPMCA4 and in 925 cells pre-treated with z-VAD-fmk

cells and in cells exposed to STS for $5 \mathrm{~h}$. In the untreated mutants, the $\mathrm{Ca}^{2+}$ transient triggered by ionomycin was rapidly rectified (trace $a$ in Figure $8 D$ ). The mutant clones undergoing apoptosis (i.e., displaying nuclear ruffling and chromatin condensation) were also able to rectify the $\mathrm{Ca}^{2+}$ transient with virtually the same kinetics as the untreated clones (trace b in Figure 8D), at variance with the wild-type, the vector-transfected and the 925 clones, where $\mathrm{Ca}^{2+}$ remained elevated after treatment with STS.

\section{Role of PMCA cleavage in apoptosis and secondary necrosis}

Apoptosis and necrosis were scored in the wild-type and mutant cell clones. Apoptosis was defined by the occurrence of cells with nuclear condensation and fragmentation, retaining plasma membrane integrity (measured by exclusion of the membrane-impermeant dye, SYTOX). Primary necrosis was defined as loss of plasma membrane integrity (SYTOX penetration) without signs of nuclear condensation or fragmentation. Secondary necrosis was determined by scoring over time cells with an apoptotic morphology, which became permeable to SYTOX. Cells were counted for up to $9 \mathrm{~h}$ after STS-exposure. At this time, the proportion of primary necrotic cells did not exceed $0.5 \%$ and was identical in both control and treated cells (data not shown). The percentage of apoptotic cells ranged between $30-45 \%$ and did not differ extensively between cell clones at $9 \mathrm{~h}$. However, at earlier time points $(5-7 \mathrm{~h})$ the number of apoptotic cells in the mutant clones was significantly lower (up to $50 \%$ less) than that observed in the corresponding control (clone 925), showing that 

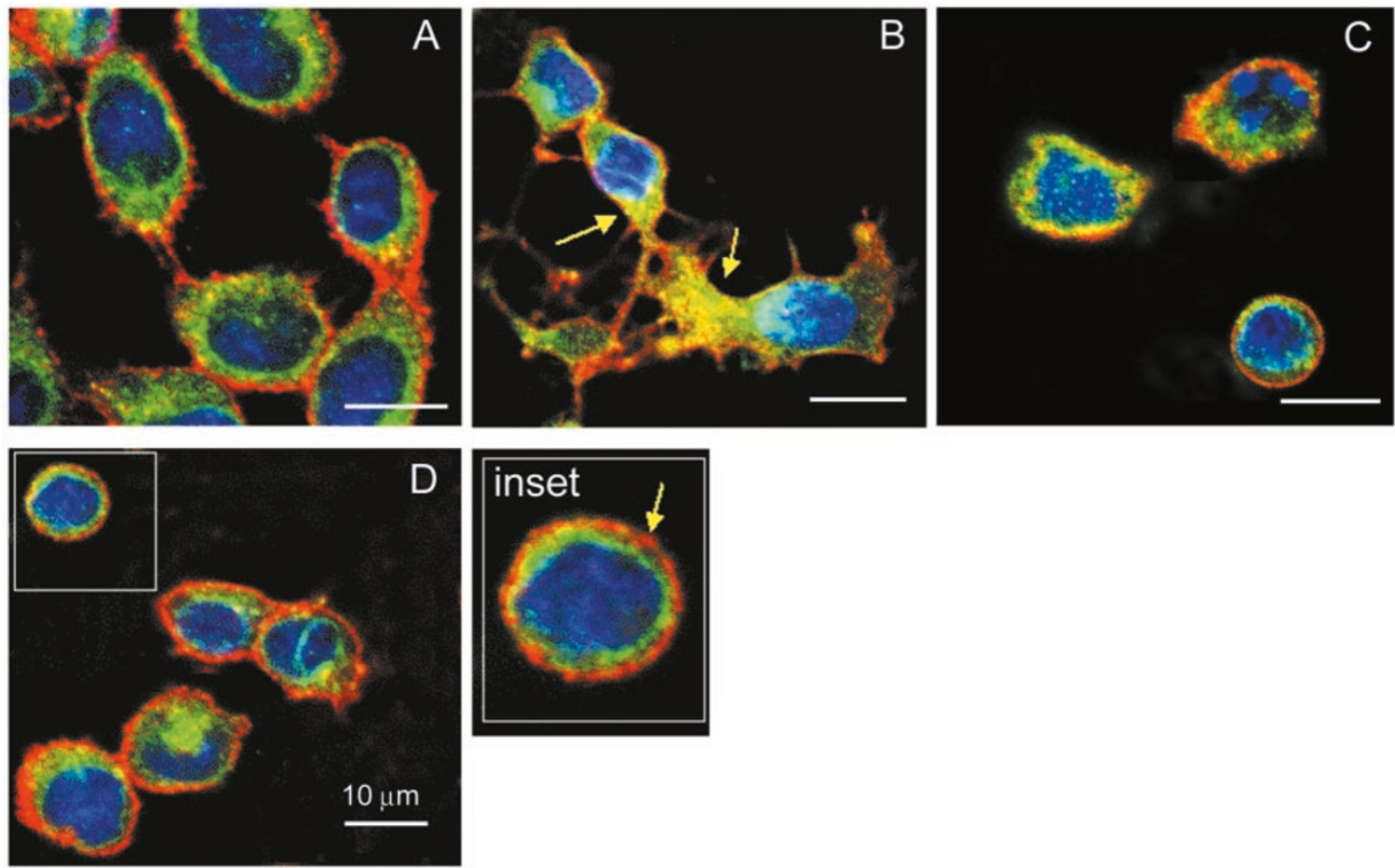

Figure 7 The subcellular relocalization of the hPMCA and SERCA pumps during apoptosis. To examine whether hPMCA translocated to ER membranes during apoptosis, cells were fixed when initial chromatin condensation became noticeable. An Alexa ${ }^{\circledR}$ goat 488 secondary antibody, which fluoresces green was used to stain the SERCA pump, whereas for hPMCA4 a goat anti-mouse Alexa ${ }^{(i m} 594$ was used (red fluorescence). Image A shows untreated cells, the other three images cells undergoing apoptosis after treatment with STS. In cells undergoing apoptosis (image B) the two stains co-localized (yellow stain indicated by arrows) in discrete subcellular regions. In the mutants (mutant $A$ and mutant $B$ in images $\mathbf{C}$ and $\mathbf{D}$ respectively) the hPMCA signal is retained intact on the plasma membrane of cells undergoing chromatin fragmentation. The SERCA pump decorated the perinuclear region probably as result of the collapse of ER membranes around the condensing nucleus (see inset)

mutation of the caspase cleavage site on PMCA4 delays apoptosis (Figure 9A).

Between 5 and $9 \mathrm{~h}$ there was a marked difference in the occurrence of secondary necrosis. SYTOX-positive cells with condensed nuclei appeared in the 925 clone, whereas the mutant clones did not lyse (Figure 9B). To further determine whether this effect would remain significant over time we measured the cumulative release of lactate dehydrogenase (LDH) from cells. LDH-release was measured for up to $20 \mathrm{~h}$ after STS-exposure. As shown in Figure 9C, the mutant clone had a significantly lower LDHrelease than clone 925. Thus, the expression of noncleavable hPMCA4 mutants slows down the kinetics of apoptosis, and drastically reduces secondary necrosis.

\section{Discussion}

\section{Cleavage of PMCAs by caspases and cell death}

Since cell death is not necessarily linked to a single program or a morphological phenotype, events that confer irreversibility to its execution would seal a cell's fate. Along with nuclear and cytoskeletal damage, disruption of cell signaling and ion homeostasis could warrant irreversibility to the death sentence. Inactivation of $\mathrm{Ca}^{2+}$-motive ATPases impairs the ability of cells to handle $\mathrm{Ca}^{2+}$ and can lead to cell demise. ${ }^{21,36}$ PMCA inhibition has been implicated in neuronal cell death elicited by amyloid- $\beta$ peptide ${ }^{37}$ or in the delayed neuronal death following ischemia in $\mathrm{CA} / 1$ hypocampal pyramidal cells. $^{38}$ Interestingly, in the latter study, PMCA activity transiently recovered after ischemia, to decay irreversibly hours after the insult. Our findings of the cleavage of PMCA2 following ischemic brain injury may provide the explanation for these early observations. The parallel increases of pump fragmentation and the apoptotic index in vivo supports the assumption that PMCA cleavage originates with apoptosis execution. The results from the cell studies provide evidence that a sub-routine of the death program, which involves caspases and targets PMCAs, sets off secondary necrosis, promoting the rapid demise of doomed cells.

On their surface, apoptotic cells present molecules (i.e., phosphatidylserines) that trigger clearance of dying cells by phagocytes. ${ }^{39,40}$ Recent work in $C$. elegans has shown that engulfing cells triggered to die by the CED-3 caspase pathway ensures their demise, preventing a potential recovery after the initial stages of death. ${ }^{41,42}$ Since $\mathrm{Ca}^{2+}$ can promote presentation of phosphatidylserines and engulfment, ${ }^{29,43}$ cleavage of PMCAs could seal cells' fate also by promoting their removal by phagocytes. Either the engulfment of dying cells or cell lysis, when scavenging capacity is limited, ${ }^{44}$ could prevent the accumulation of doomed, but 'undead' cells.

Caspase activation does not necessarily require elevation of intracellular $\mathrm{Ca}^{2+}$. Nevertheless, $\mathrm{Ca}^{2+}$ chelators or 

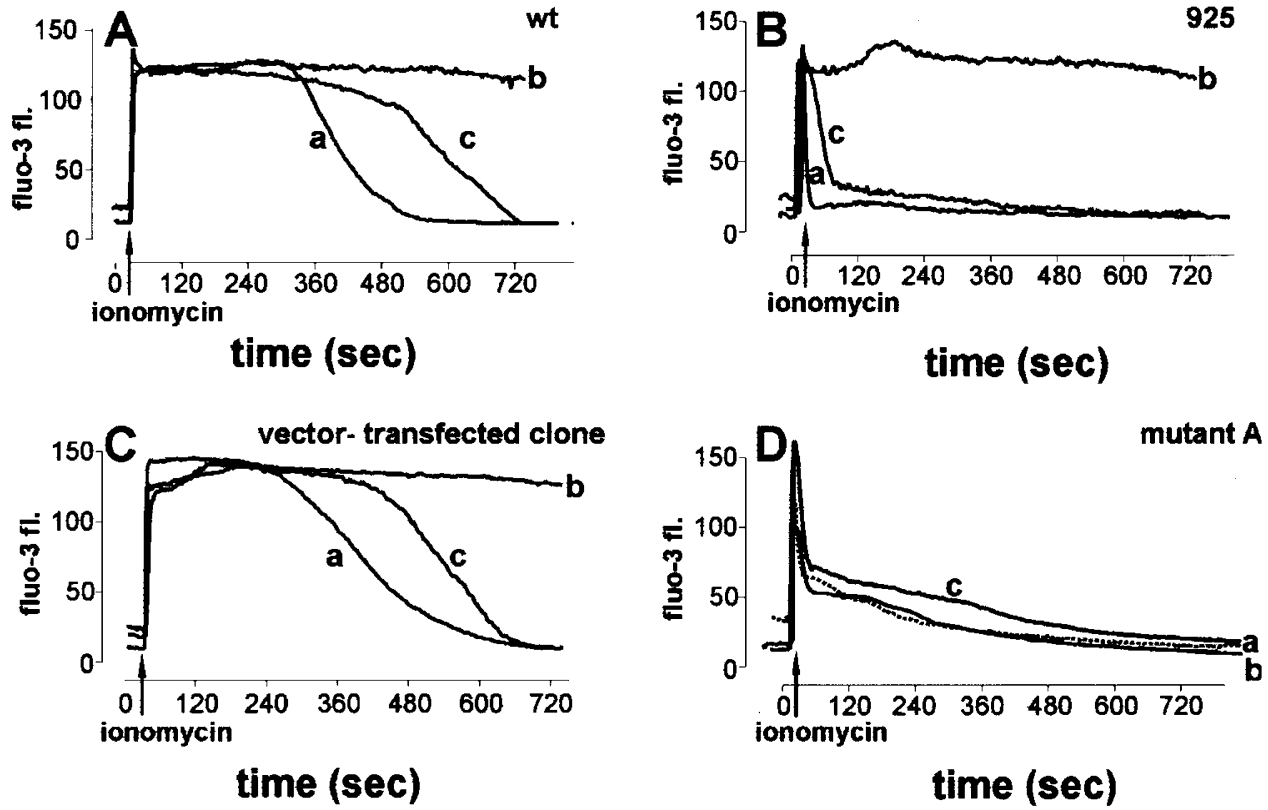

Figure 8 Altered intracellular $\mathrm{Ca}^{2+}$ responses in apoptotic cells are restored in the clones expressing caspase non-cleavable mutants. Intracellular free calcium was measured by using the fluorescent $\mathrm{Ca}^{2+}$ indicator fluo-3-AM (Molecular Probes Europe BV, Leiden, The Netherlands). Fluo-3 fluorescence is expressed in arbitrary units (y-axis). Each curve is a response from an individual cell. All cells examined responded virtually with the same patterns, but with variable amplitudes. Over 100 cells were examined in each experimental condition in three separate experiments. Changes in [Ca $\left.{ }^{2+}\right]_{i}$ were measured using a Leica DM IRB confocal microscope equipped with a Krypton-Argon laser at a wavelength of $488 \mathrm{~nm}$. Acquired data were processed by using the software Microsoft Excel and Graphpad Prism. (A) wt cells; (B) 925 cells; (C) vector transfected cells; (D) Mutant A. Cells were loaded with $15 \mu \mathrm{M}$ fluo-3-AM and then stimulated with $1 \mu \mathrm{M}$ ionomycin as indicated by the arrows: trace a represents the typical response of untreated cells; trace $\mathrm{b}$ is the response detected in cells treated for $5 \mathrm{~h}$ with $1 \mu \mathrm{M}$ STS to induce apoptosis; in trace c, cells were treated with $100 \mu \mathrm{M}$ of the caspase-inhibitor z-VAD-fmk for 30 min prior to treatment with staurosporine at a final concentration of $1 \mu \mathrm{M}$ for $5 \mathrm{~h}$. After loading the cells with fluo-3-AM, measurements were performed as described above

channel blockers can rescue part of the death program in paradigms, where $\mathrm{Ca}^{2+}$ is not the initial death signal. ${ }^{45}$ Several amplification loops have been suggested between the caspase execution pathway and disturbances in intracellular $\mathrm{Ca}^{2+}$. These include activation of signaling proteins, ${ }^{24}$ transcriptional factors ${ }^{46}$ and other protease families. ${ }^{29,47}$ Rising $\mathrm{Ca}^{2+}$ levels, as seen in cells where $\mathrm{Ca}^{2+}$ extrusion is compromised, may then affect execution of apoptosis, in addition to promotion of secondary lysis. The slower kinetics of apoptosis observed in our noncleavable mutants suggest that cleavage of PMCAs can be sufficient to recruit $\mathrm{Ca}^{2+}$ requiring pathways in the execution of apoptosis also when $\mathrm{Ca}^{2+}$ signals are not the initial death trigger.

\section{Cleavage site and mechanism of pump inactivation}

Our findings that different PMCA isoforms are cleaved in both neurons and non-neuronal cells suggest that pump cleavage may be common to several death paradigms. Adult neurons express both PMCA2 and PMCA4, with the neuronal isoform being predominant under culture conditions. ${ }^{26}$ Both caspases-1 and -3 may in principle be responsible for PMCA2 cleavage in vivo, since both caspases are activated in ischemic settings ${ }^{3,48}$ and both caspases can cleave PMCA2 in our in vitro experiments. The cleavage pattern of PMCA2 in CGN exposed to excitotoxins or in ischemic brain reveals a major $123 \mathrm{kDa}$ product that is consistent with a cleavage site proximal to the C-terminus of the pump, analogous to the caspase-3 cleavage site on PMCA4. The sequence of PMCA2 shows at least two potential caspase-3 cleavage sites (1066-1072 DVEE; EEID) in the protruding C-terminus portion of the molecule that may generate the $123 \mathrm{kDa}$ product. To further investigate which caspase is primarily responsible for the generation of the $123 \mathrm{kDa} \mathrm{PMCA}^{*}$, we have used the selective caspase- 3 inhibitor, M791. ${ }^{49}$ Our initial experiments have shown that PMCA2 cleavage to $123 \mathrm{kDa}$ is predominantly, but not completely mediated by caspase-3 (data not shown). Since the protection afforded by the pan-caspase inhibitors was complete, other caspases (i.e., caspase-1, which is active in the cleavage assay in vitro) may contribute to degradation of PMCA2. The pump fragmentation observed in the in vitro experiments is more extensive than that found in neurons and ischemic brain tissue. It is conceivable that the conditions prevailing in the in vitro cleavage experiments (i.e., concentrations of caspases and substrate) reveal additional low-affinity cleavage sites. Additional possible cleavage sites for caspases (e.g., FVLD at residues 577-580) are likely to be responsible for the formation of the main $40 \mathrm{kDa}$ fragment observed in vitro. The inhibitor experiments and the analogy with the unequivocal cleavage pattern of PMCA4, strongly support the conclusion that PMCA2 cleavage in vivo is restricted to the C-terminus portion of the molecule. 

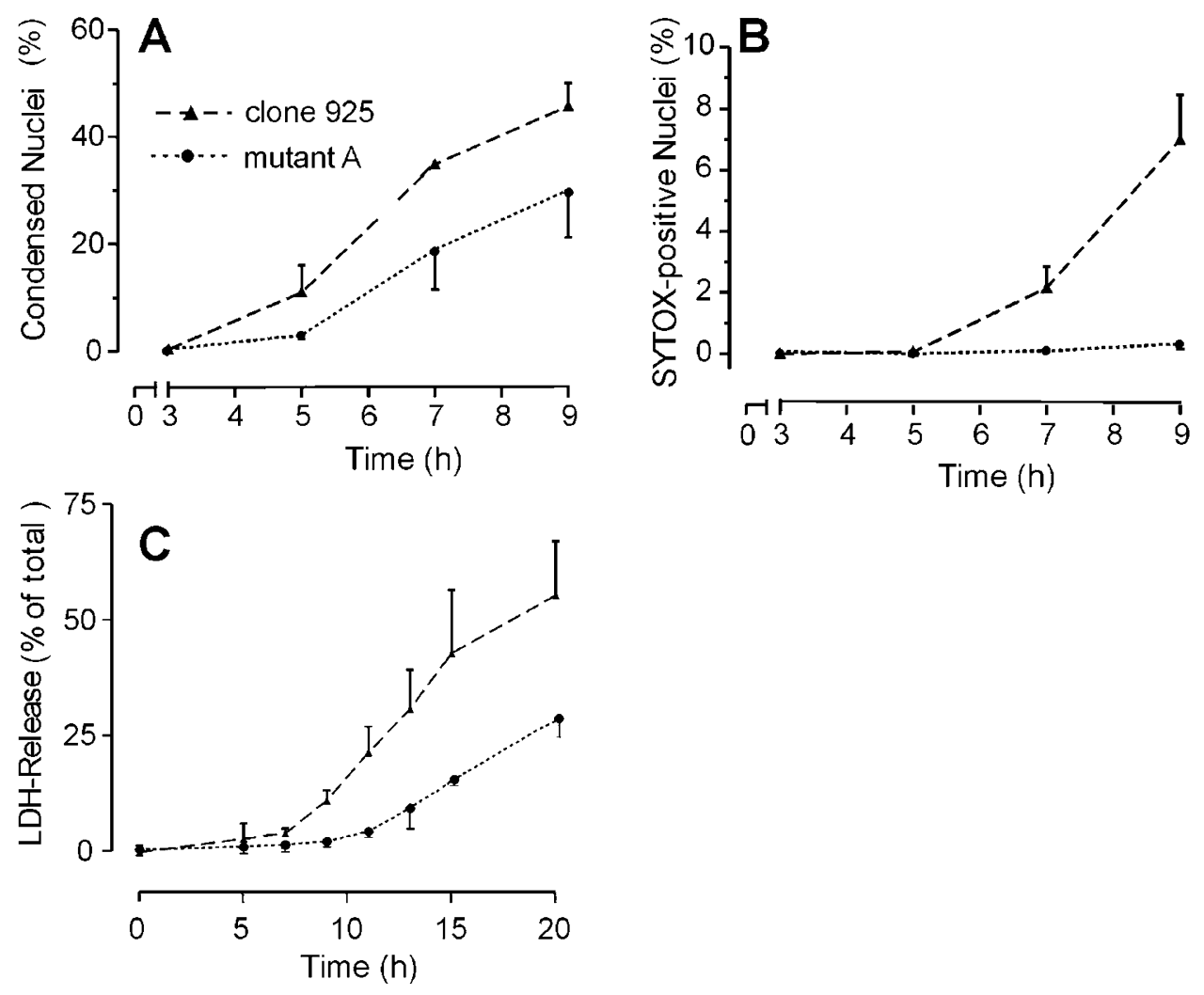

Figure 9 Apoptosis and secondary necrosis in 925 and mutant A clones. (A) Apoptosis was scored by the number of condensed hyperfluorescent nuclei (stained $0.5 \mu \mathrm{M}$ of the membrane permeant, Hoechst 33342) after treatment with $1 \mu \mathrm{M} \mathrm{STS}$. (B) Secondary necrosis was assessed by staining cultures with $0.5 \mu \mathrm{g}$ SYTOX, a membrane impermeant DNA dye. Cells undergoing secondary necrosis presented condensed and fragmented nuclei and were positive to SYTOX. (C) Release of $\mathrm{LDH}^{21}$ was used to follow the extent of secondary necrosis over $20 \mathrm{~h}$. The number of primary necrotic cells (i.e., SYTOX positive, without the morphological features of apoptosis) was $<0.5 \%$ in all experiments. Three independent experiments comprising triple sets of data were performed. Average and standard deviation were calculated in Microsoft Excel. The differences in LDH-release between the 925 and the $\mathrm{CHO}$ clone mutant A were analyzed by the ANOVA test for repeated measurements. Assuming equal variance among clones, the difference proved to be significant with $P=0.047$ and $F_{1.4}=74$

Our results also show that C-terminally truncated forms of the PMCA can be functionally inactive. Normally the Cterminal cytosolic portion of the pump that contains the calmodulin binding region folds close to sites near to the active center of the molecule, acting as an auto-inhibitory domain. ${ }^{50}$ Its removal by other proteases, e.g. calpains, makes the pump constitutively active. ${ }^{51}$ The caspase- 3 cleavage site on PMCA4 is located on the $\mathrm{N}$-terminal side of the calmodulin binding domain, only a few residues upstream of the activatory cleavage site by calpain. Thus, it seems unlikely that the inactivation of the pump in cells is due to conformational changes or to changes at the active site. A more plausible explanation for the complete PMCA inactivation found in our experiments is that caspase cleavage promotes its further degradation. Caspase cleavage exposes a domain with high frequency of acidic residues and a high PEST score, which facilitates pump degradation when exposed in truncated mutants. ${ }^{34}$ Upon caspase activation, PMCA disappears from the plasma membrane of individual cells suggesting that the pump is fully degraded either in situ or after redistribution to internal compartments. Co-localization of PMCA4 and the SERCA pump in cells with initial signs of chromatin condensation suggests that the pump can be internalized within ER structures. Notably, the PMCA4 $119 \mathrm{kDa}$ degradation product, PMCA4* (Figure 2) is still capable of forming a weak phosphorylated intermediate in vitro. PMCA4* would, however, hardly function to pump $\mathrm{Ca}^{2+}$ outside the cell as the pump appears to be removed from the plasma membrane and internalized within the ER. This is confirmed by the total loss of the ability of the cells to rectify $\mathrm{Ca}^{2+}$ transients after caspase activation. It is remarkable that the SERCA pump remains intact until the late phases of apoptosis, when it can be seen nicely decorating the perinuclear region probably as part of the collapse of ER membranes around the nucleus. ${ }^{52}$ Intranuclear $\mathrm{Ca}^{2+}$ uptake is controlled in part by a $\mathrm{Ca}^{2+}$ pump, ${ }^{53}$ likely located on the nuclear envelope, which shares close similarity with the SERCA pump. ${ }^{54}$ Activation of the nuclear $\mathrm{Ca}^{2+}$ pump has been shown to promote DNA fragmentation in isolated nuclei preparations. ${ }^{55}$ Since the SERCA pump remains active (see phosphorylation experiments), it may function to supply $\mathrm{Ca}^{2+}$ to the perinuclear space and the nuclear interior to promote chromatin fragmentation in addition to caspase-dependent mechanisms of chromatin degradation. 56 


\section{Inactivating cleavage of PMCA, $\mathrm{Ca}^{2+}$ overload and neuronal survival}

To balance the downhill inflow of $\mathrm{Ca}^{2+}$ into cells and its release from intracellular stores, PMCAs remove $\mathrm{Ca}^{2+}$ from the cytosol, maintaining the low intracellular free $\mathrm{Ca}^{2+}$ concentration necessary to its second messenger function. Calmodulin-bound PMCA has a high affinity for $\mathrm{Ca}^{2+}$. Its activity is therefore quite effective to maintain or restore a low set point for cytosolic $\mathrm{Ca}^{2+}{ }^{27}$ Thus, PMCAs are transcriptionally regulated in differentiating CGN, most likely to fine-tune the $\mathrm{Ca}^{2+}$ set point in post-mitotic neurons. ${ }^{26}$ In excitable cells, the $\mathrm{Na}^{+} / \mathrm{Ca}^{2+}$ transporter (NCX) drives $\mathrm{Ca}^{2+}$ efflux, in addition to PMCAs. ${ }^{57} \mathrm{NCX}$ has a low $\mathrm{Ca}^{2+}$ affinity, but high $\mathrm{Ca}^{2+}$ transporting velocity, which is required to rapidly eject large amounts of $\mathrm{Ca}^{2+}{ }^{28}$ While the NCX contribution in regulating resting cytosolic $\mathrm{Ca}^{2+}$ may be less important than that of PMCAs, its function may prevent $\mathrm{Ca}^{2+}$ overload in stimulated cells undergoing apoptosis. However, preliminary results in our laboratories show that NCX1 is cleaved by caspase -3 in CGN undergoing apoptosis and suggest that cleavage of plasma membrane $\mathrm{Ca}^{2+}$ transporters is a relevant subroutine of the neuronal death program.

\section{PMCA cleavage and the switch apoptosis/necrosis}

The mode of neuronal cell death in brain ischemia has been a matter of controversy. Evidence from stroke models suggests that necrosis predominates in the more severely stressed core area, whereas apoptotic neurons are primarily localized in the penumbra area of focal ischemia, where the insult is milder. ${ }^{59,60}$ The primary switch in the decision between necrosis and apoptosis depends on various factors, including the intensity of the insult, ${ }^{23,28}$ the degree of the initial $\mathrm{Ca}^{2+}$ overload, ${ }^{61}$ and the intracellular ATP levels. ${ }^{7,23}$ The data presented here reveal a secondary switch that may explain why necrotic features can be attributed to events that are dependent on caspase activation and downstream of the initiation of programmed cell death. Linking caspase activation to secondary necrosis provides a possible explanation for the global protective effect of caspase inhibitors in ischemia paradigms. ${ }^{8}$ Additionally, they may further rationalize the synergistic effect of the combined treatment with caspase inhibitors and $\mathrm{Ca}^{2+}$ channel blockers. ${ }^{62}$

Caspases cleave only a relatively small fraction of the cellular proteome. ${ }^{1}$ The resulting loss or gain of function gives rise to the morphological and biochemical features typical of apoptosis. However, not all substrates are equally critical for cell death. Some are part of the subroutines of the death program that may be dispensable. For example, the caspase-3 mediated degradation of ICAD ${ }^{56}$ determines whether DNA laddering occurs in a dying cell. The latter, however, is not strictly required for cell killing or disposal, but may be relevant for an orderly burial. ${ }^{63}$ Our finding suggests that PMCAs are vital caspase substrates and that the subroutine of the death program leading to secondary lysis is not a merely passive phenomenon. The prolonged survival of the PMCA mutants also shows that this branch of the death program requires caspase activation, and distinguishes secondary lysis from primary necrosis, which occurs by caspase- and ATP-independent mechanisms.

\section{Materials and Methods}

\section{Neonatal hypoxic-ischemic brain injury}

Neonatal P7 Sprague-Dawley rats received left common carotid artery ligation and exposure to $8 \%$ oxygen/92\% nitrogen for $2.5 \mathrm{~h} .{ }^{27}$ The animals were returned to their cages and then euthanized $24 \mathrm{~h}$ later. The left (ipsilateral) and right (contralateral) cortical brain sections were dissected. The degree of injury, assessed by brain swelling, was determined for each animal and assigned a severity score from 0 (no injury) to 3 (most severe). Each cortical sample was homogenized in lysis buffer (1\% (v/v) Nonidet P40, 2 mM EDTA, 50 mM Tris ( $\mathrm{pH} 7.5)$, Roche Complete ${ }^{\circledR}$ protease inhibitor cocktail, and the poly-caspase inhibitor MF033) for $5 \mathrm{~s}$ using an Ultra-Turrax T8 homogenizer. Following $30 \mathrm{~min}$ of standing on ice, the lysates were clarified by centrifugation at $10000 \times \mathrm{g}$ for $10 \mathrm{~min}$ at $4^{\circ} \mathrm{C}$. Protein concentration was then determined using the Pierce BCA assay. Western blotting was performed using affinity-purified isoform specific rabbit antiPMCA2 polyclonal antibodies diluted 1:1000. Apoptotic DNA fragmentation was quantified by assaying $10 \mu \mathrm{g}$ of each lysate using the Roche Cell Death ELISA. For Western blot analysis, $50 \mu \mathrm{g}$ of each lysate was loaded and subjected to electrophoresis on a $4-20 \%$ gradient gel (lysates from CGN treated with PBS or $25 \mu \mathrm{M} \mathrm{L}$-glutamate were included as controls; not shown). Following electrophoretic transfer to nitrocellulose, the blots were probed with 1/1000 dilution of the $2 \mathrm{~N}$ antibody, followed by $1 / 5000$ dilution of anti-rabbit HRP antibody. The signal was developed using the Pierce Femto substrate. A densitometric scan of the exposed film was used to quantify the level of $\mathrm{p} 123$ produced relative to $\mathrm{p} 132$.

\section{Cell cultures}

Primary cultures of mouse CGN were grown for 7 days on 12-well plates $\left(1.2 \times 10^{6}\right.$ cells per well) as described previously. ${ }^{30}$ Spodoptera frugiperda (Sf9) cells were grown in TNM-FH (Sigma, Division of Fluka, Buchs, Switzerland) and used to express full-length hPMCA2 and hPMCA4 or truncated hPMCA4s $(\Delta 44$ and $\Delta 139)$ as described in detail elsewhere. ${ }^{64}$ CHO-K1 (ATCC No. CCL 61) cells were maintained in Glasgow minimal Eagle's medium (GMEM) (GIBCO Life Technologies) supplemented with $10 \%$ dialyzed FCS, $100 \mu \mathrm{g} / \mathrm{ml}$ gentamicin, amino acids, nucleotides, and pyruvate. ${ }^{65} \mathrm{HeLa}$ S3 cells were cultured in DMEM (Dulbecco's modified Eagle medium) supplemented with $5 \%$ heath inactivated FCS, 2 mM glutamine, 100 units $/ \mathrm{ml}$ penicillin and $100 \mu \mathrm{g} / \mathrm{ml}$ streptomycin.

\section{Site directed mutagenesis and transfections}

Chinese hamster ovary $(\mathrm{CHO})$ cell lines transfected with the vector control (clone 4150) or overexpressing hPMCA4 (clone 925) were generated as described previously. ${ }^{66}$ To generate hPMCA4 mutants we used a plasmid construct (pSG5-PMCA4) composed of the fulllength human cDNA (GenBank Accession \#M25874) of PMCA4b excised between bp390 and 4020 from the pVL-PMCA with BamHI and Kpnl, and ligated into the vector pSG5 at BamHI and Kpnl restriction sites in the multiple cloning site (MCS). ${ }^{67}$ Two different oligonucleotides were synthesized for site-directed mutagenesis of the two aspartic acid residues in the putative caspase- 3 cleavage site DEID. One point mutation (adenosine $\rightarrow$ cytosine) at bp 3636 (mutant A) or at bp 3627 (mutant B) changed the codon for aspartic acid into 
one for alanine, at positions 1080 or 1077 , respectively. Mutagenesis was carried out using the GeneEditor ${ }^{(i x}$ in vitro Site-Directed Mutagenesis System (Promega Inc. Madison, WI, USA).

The plasmids pSG5-PMCA4-D1080A and -D1077A were purified using an Endofree Maxi Kit and transfected into $\mathrm{CHO}$ cells via the LipofectAMINE $^{\mathbb{R}} 2000$ Reagent (Life Technologies, Eggenstein, Germany). Transfection reagent $(15 \mu \mathrm{l})$ and $8 \mu \mathrm{g}$ plasmid DNA per well were incubated with $\mathrm{CHO}$ cells (approximately $95 \%$ confluence) in a 6-well culture plate for $4 \mathrm{~h}$. The cells were co-transfected with the vector pPUR (Clontech Laboratories Inc., Palo Alto, CA, USA) to introduce resistance to puromycin. The plasmids pSG5-PMCA4 and pPUR were applied in a molar ratio of $5: 1$ to ensure selection of cells transfected with pSG5-PMCA4.

Following transfection, the cells were allowed to double under nonselective conditions for $24 \mathrm{~h}$ after which they were removed and plated on $10 \mathrm{~cm}$ petri dishes. Puromycin was added $24 \mathrm{~h}$ after plating at a final concentration of $5 \mu \mathrm{g} / \mathrm{ml}$. Colonies were selected after $10-12$ days and clones expressing hPMCA4 were cultured and used for experiments between passages 5-20.

\section{Cleavage of PMCAs in excitotoxin- or staurosporine-induced apoptosis}

Glutamate $(60 \mu \mathrm{M})^{23}$ or the indirect excitotoxins $\mathrm{MPP}^{+}(50 \mu \mathrm{M})$ and GSNO $(300 \mu \mathrm{M})^{29,30}$ were used to trigger apoptosis in CGNs. STS $(1 \mu \mathrm{M})$ was used to elicit apoptosis in wt and PMCA-overexpressing $\mathrm{CHO}$ cells, and in HeLa cells. When chromatin condensation started to appear cells were rapidly harvested from culture plates and resuspended at a concentration of $5-10 \times 10^{6} / \mathrm{ml}$ in a Tris/EDTA buffer (10 mM Tris/HCl, pH 8.0, $1 \mathrm{mM}$ EDTA, $5 \mu \mathrm{g} / \mathrm{ml}$ leupeptin, $5 \mu \mathrm{g} /$ $\mathrm{ml}$ aprotinin, $5 \mu \mathrm{g} / \mathrm{ml}$ pepstatin). Lysis was performed by three cycles of freeze and thaw $\left(-70^{\circ} / 37^{\circ} \mathrm{C}\right)$ and the insoluble proteins were sedimented at $15000 \times g$ for $15 \mathrm{~min}\left(4^{\circ} \mathrm{C}\right)$. The supernatants, which did not contain PMCAs, were discarded. The pellets were resuspended in a buffer containing $8 \mathrm{M}$ urea, $0.5 \mathrm{M} \mathrm{DTT}, 5 \%$ SDS, $5 \mathrm{mM}$ EDTA, $50 \mathrm{mM}$ Tris/ $\mathrm{HCl} \mathrm{pH} 8$ and bromophenol blue, and run on SDS gels. Western blotting was performed using affinity-purified isoform specific rabbit polyclonal antibodies; anti-PMCA2 antibody: diluted 1:1000 and anti-PMCA4 antibodies: diluted 1:500. ${ }^{26,68} \mathrm{~A}$ secondary goat anti-rabbit antibody, conjugated with alkaline phosphatase, was added in a dilution of $1: 7500$.

\section{Cleavage of PMCAs in Sf-9 or CHO membrane fractions}

Membrane fractions (600 ng protein) derived from Sf-9 cells expressing either hPMCA2 or hPMCA $4^{64}$ and from $\mathrm{CHO}$ cells expressing full-length or truncated hPMCA4s were incubated in an Eppendorf Thermomixer at $37^{\circ} \mathrm{C}$ and 700 r.p.m. with $60 \mathrm{ng}$ of purified caspases- $1,-3,-4,-7$ or -8 in a final volume of $20 \mu \mathrm{l}$. For caspase- 1 the buffer contained $100 \mathrm{mM}$ HEPES pH 7.5, $10 \%$ sucrose, and $0.1 \%$ CHAPS. A buffer containing $50 \mathrm{mM}$ HEPES pH 7.5, $1 \%$ sucrose, and $0.1 \%$ CHAPS was used for the other caspases. Both buffers were supplemented with $10 \mathrm{mM}$ DTT. The reaction was stopped by adding $20 \mu \mathrm{l}$ of sample buffer (8 M urea, $0.5 \mathrm{M} \mathrm{DTT}, 5 \%$ SDS, $5 \mathrm{mM}$ EDTA, $50 \mathrm{mM}$ Tris/ $\mathrm{HCl} \mathrm{pH} \mathrm{8,} \mathrm{and} \mathrm{bromphenol} \mathrm{blue).} \mathrm{The} \mathrm{samples} \mathrm{were}$ separated by SDS-PAGE (polyacrylamide gel electrophoresis). Gels were blotted on nitrocellulose using the antibodies described above.

\section{Determination of the phosphoenzyme intermediate}

The formation of the PMCA-specific phosphorylated enzyme intermediate from ATP was carried out on membrane fractions expressing
hPMCA2 or hPMCA4. Membrane proteins $(25-50 \mu \mathrm{g})$ were resuspended in $50 \mu$ l of $20 \mathrm{mM}$ MOPS/KOH, $\mathrm{pH} 6.8,100 \mathrm{mM} \mathrm{KCl}$ in the presence of $100 \mu \mathrm{M} \mathrm{Ca}^{2+}$ plus $100 \mu \mathrm{M} \mathrm{LaCl}_{3}$ and incubated with caspase-1 or caspase-3 for up to $60 \mathrm{~min}$. At each time point, the reaction was started on ice by adding $0.3 \mu \mathrm{M}\left[{ }^{32} \mathrm{P}-\gamma\right]$-ATP $(150-$ $300 \mathrm{Ci} / \mathrm{mmol}$ ), followed by vigorous mixing on a Vortex. After $30 \mathrm{~s}$ on ice, the reaction was stopped by the addition of $7 \%$ trichloroacetic acid (TCA). Pellets were washed once in 7\% TCA and $1 \mathrm{mM}$ phosphate and once in water before separation on acidic gels. ${ }^{69}$ After drying, the gels were analyzed on autoradiograms exposed to X-ray films at $-70^{\circ} \mathrm{C}$, for $1-3$ days.

\section{Intracellular free $\left[\mathrm{Ca}^{2+}\right]$}

$\mathrm{Ca}^{2+}$ transients were measured in single $\mathrm{CHO}$ cells by confocal microscopy. Since we were interested in the recovery kinetics following $\mathrm{Ca}^{2+}$ transients, we used the $\mathrm{Ca}^{2+}$-indicator fluo-3-AM (acetoxymethylester) because of its uniform loading in $\mathrm{CHO}$ cells and minimal photo bleaching under the duration of our experiments. $\mathrm{CHO}$ cells were loaded with $15 \mu \mathrm{M}$ fluo-3 AM for $30 \mathrm{~min}$ at $37^{\circ} \mathrm{C}$ in a CSS -5 medium $(120 \mathrm{mM} \mathrm{NaCl}, 5 \mathrm{mM} \mathrm{KCl}, 0.8 \mathrm{mM}$ $\mathrm{MgCl}_{2}, 1.8 \mathrm{mM} \mathrm{CaCl}$, $15 \mathrm{mM}$ glucose, and $25 \mathrm{mM} \mathrm{HEPES}$, $\mathrm{pH} 7.4$ ) supplemented with $1 \%$ BSA. To ensure the complete deesterification of fluo-3, cells were washed in CSS-5 and left at room temperature for an additional $10 \mathrm{~min}$. The measurements were performed at $27^{\circ} \mathrm{C}$ using a Leica TCS-4D confocal microscope (Leica Mikrosysteme Vertrieb $\mathrm{GmbH}$, Bensheim, Germany) with a $40 \times$ oil immersion lens. Fluo-3 was excited using a krypton/argon laser at a wavelength of $488 \mathrm{~nm}$, and emitted fluorescence was collected using a $520 \mathrm{~nm}$ band pass filter. Relative mean fluorescence intensities were collected from defined regions of interest using the ion domain software (Leica Mikrosysteme Vertrieb $\mathrm{GmbH}$, Bensheim, Germany). Cells were stimulated with $1 \mu \mathrm{M}$ ionomycin. In each experiment, 45-50 cells were analyzed. The recovery time after the ionomycin pulse was recorded and compared between the different clones.

\section{PMCA localization}

For immunocytochemistry, we used an antibody that recognizes an epitope in the large central cytoplasmic loop of hPMCA4 between amino acids residues $724-783 .^{68}$ Staining therefore was not directly affected by the caspase cleavage of the pump, which occurs at the C-terminus. The Alexa 594 goat anti mouse IgG conjugate was used as secondary antibody (Molecular Probes Europe BV, Leiden, Netherlands). Cells were plated on glass coverslips in a 24-well culture plate and grown for $48 \mathrm{~h}$. Both untreated and STS-treated cells were fixed for $15 \mathrm{~min}$ at room temperature using $2 \%$ PFA, $0.1 \%$ picric acid, and $5 \%$ glacial acetic acid in $\mathrm{H}_{2} \mathrm{O}$. Cells were then permeabilized for 5 min with $0.1 \%$ Triton $\mathrm{X}-100$ in PBS. Blocking of unspecific binding sites was performed for $1 \mathrm{~h}$ with $1 \% \mathrm{BSA}$ in PBS, followed by incubation with a primary mouse antibody diluted $1: 500$ in $0.1 \%$ BSA in PBS for $1 \mathrm{~h}$ and with the secondary antibody, diluted $1: 500$ in $0.1 \%$ BSA in PBS, under the same conditions. SERCA was stained using a rabbit polyclonal antibody followed by a secondary goat anti-mouse Alexa 488 antibody. Nuclear staining was achieved using Hoechst-33342 at a final concentration of $250 \mathrm{ng} / \mathrm{ml}$ in PBS for $5 \mathrm{~min}$. Cells were loaded with $1 \mu \mathrm{M}$ fixable CellTracker ${ }^{(i)}$ Green CMFDA (5-chloromethylfluorescein diacetate) to stain the cytoplasm. The probes were analyzed using a confocal microscope TCS 4D UV/VIS equipped with an argon/krypton ion laser system. 


\section{Acknowledgements}

This study was supported by grants from the DFG Ni-519/1-1 and 519/21 , by funds from Telethon (to $E$ Carafoli), by the British Medical Research Council and by the EC grant Nicotine and Ageing.

\section{References}

1. Nicholson DW (1999) Caspase structure, proteolytic substrates, and function during apoptotic cell death [In Process Citation]. Cell Death Differ 6: 1028-1042

2. Earnshaw WC, Martins LM andKaufmann SH (1999) Mammmalian caspases:structure activation, substrates, and functions during apoptosis. Annu. Rev. Biochem. 68: 383-424

3. Kang SJ, Wang S, Hara H, Peterson EP, Namura S, Amin-Hanjani S, Huang Z, Srinivasan A, Tomaselli KJ, Thornberry NA, Moskowitz MA and Yuan J (2000) Dual role of caspase-11 in mediating activation of caspase- 1 and caspase-3 under pathological conditions. J Cell Biol 149: 613-622

4. Nicotera P, Leist M and Manzo L (1999) Neuronal cell death: a demise with different shapes. TiPS 20: $46-51$

5. Volbracht C, Leist M, Kolb SA and Nicotera P (2001) Apoptosis in caspaseinhibited neurons. Mol Med. 7: 36-48

6. Krammer PH (1996) The CD95(APO-1/Fas) receptor/ligand system: death signals and diseases. Cell Death Differ. 3: 159-160

7. Leist M, Single B, Castoldi AF, Kühnle S and Nicotera P (1997) Intracellular ATP concentration: a switch deciding between apoptosis and necrosis. J. Exp. Med. 185: $1481-1486$

8. Hara H, Fink K, Endres M, Friedlander RM, Gagliardini V, Yuan J and Moskowitz MA (1997) Attenuation of transient focal cerebral ischemic injury in transgenic mice expressing a mutant ICE inhibitory protein. J. Cereb. Blood Flow Metab. 17: $370-375$

9. Hara H, Friedlander RM, Gagliardini V, Ayata C, Fink K, Huang Z, ShimizuSasamata M, Yuan J and Moskowitz MA (1997) Inhibition of interleukin 1beta converting enzyme family proteases reduces ischemic and excitotoxic neuronal damage. Proc. Natl. Acad. Sci. USA 94: 2007-2012

10. Robertson GS, Crocker SJ, Nicholson DW and Schulz JB (2000) Neuroprotection by the inhibition of apoptosis. Brain Pathol 10: 283-292

11. Choi DW (1996) Ischemia-induced neuronal apoptosis. Curr. Opin. Neurobiol. 6 : 667-672

12. Linnik MD, Zobrist RH and Hatfield MD (1993) Evidence supporting a role for programmed cell death in focal cerebral ischemia in rats. Stroke 24: 2002-2008; discussion 2008-2009

13. Hara H, Friedlander RM, Gagliardini V, Ayata C, Fink K, Huang Z, ShimizuSasamata M, Yuan J and Moskowitz MA (1997) Inhibition of interleukin 1beta converting enzyme family proteases reduces ischemic and excitotoxic neuronal damage. Proc. Natl. Acad. Sci. USA 94: 2007-2012

14. Dirnagl U, ladecola C and Moskowitz MA (1999) Pathobiology of ischaemic stroke: an integrated view. Trends Neurosci. 22: 391-397

15. Rabuffetti M, Sciorati C, Tarozzo G, Clementi E, Manfredi AA and Beltramo M (2000) Inhibition of caspase-1-like activity by Ac-Tyr-Val-Ala-Asp-chloromethy ketone induces long-lasting neuroprotection in cerebral ischemia through apoptosis reduction and decrease of proinflammatory cytokines. J Neurosci 20 : 4398-4404

16. Rosenbaum DM, Gupta G, D'Amore J, Singh M, Weidenheim $\mathrm{K}$, Zhang $\mathrm{H}$ and Kessler JA (2000) Fas (CD95/APO-1) plays a role in the pathophysiology of focal cerebral ischemia. J. Neurosci. Res. 61: 686-692

17. Martin-Villalba A, Hahne M, Kleber S, Vogel J, Falk W, Schenkel J and Krammer $\mathrm{PH}$ (2001) Therapeutic neutralization of CD95-ligand and TNF attenuates brain damage in stroke. Cell Death Differ 8: 679-686

18. Künstle G, Leist M, Uhlig S, Revesz L, Feifel R, MacKenzie A and Wendel A (1997) ICE-protease inhibitors block murine liver injury and apoptosis caused by CD95 or TNF-alpha. Immunol. Lett. 55: 5-10

19. Chan SL, Griffin WS and Mattson MP (1999) Evidence for caspase-mediated cleavage of AMPA receptor subunits in neuronal apoptosis and Alzheimer's disease. J. Neurosci. Res. 57: 315-323

20. Glazner GW, Chan SL, Lu C and Mattson MP (2000) Caspase-mediated degradation of AMPA receptor subunits: a mechanism for preventing excitotoxic necrosis and ensuring apoptosis. J. Neurosci. 20: 3641-3649
21. Nicotera P, Hartzell P, Baldi C, Svensson S-A, Bellomo G and Orrenius S (1986) Cystamine induces toxicity in hepatocytes through the elevation of cytosolic $\mathrm{Ca} 2+$ and the stimulation of a nonlysosomal proteolytic system. J. Biol. Chem. 261: $14628-14635$

22. Nicotera $P$ and Orrenius $S$ (1994) Molecular mechanisms of toxic cell death: an overview (New York: Academic Press)

23. Ankarcrona M, Dypbukt JM, Bonfoco E, Zhivotovsky B, Orrenius S, Lipton SA and Nicotera P (1995) Glutamate-induced neuronal death: a succession of necrosis or apoptosis depending on mitochondrial function. Neuron. 15: $961-$ 973

24. Wang HG, Pathan N, Ethell IM, Krajewski S, Yamaguchi Y, Shibasaki F, McKeon F, Bobo T, Franke TF and Reed JC (1999) Ca2+-induced apoptosis through calcineurin dephosphorylation of BAD. Science $284: 339-343$

25. Nakagawa $T$ and Yuan $J(2000)$ Cross-talk between two cysteine protease families. Activation of caspase-12 by calpain in apoptosis. J. Cell. Biol. 150: 887-894

26. Guerini D, Garcia-Martin E, Gerber A, Volbracht C, Leist M, Merino CG and Carafoli $E$ (1999) The expression of plasma membrane Ca2+ pump isoforms in cerebellar granule neurons is modulated by Ca2+. J. Biol. Chem. 274: 16671676

27. Han BH, DeMattos RB, Dugan LL, Kim-Han JS, Brendza RP, Fryer JD, Kierson M, Cirrito J, Quick K, Harmony JA, Aronow BJ and Holtzman DM (2001) Clusterin contributes to caspase-3-independent brain injury following neonatal hypoxiaischemia. Nat. Med. 7: 338-343

28. Bonfoco E, Leist M, Zhivotovsky B, Orrenius S, Lipton SA and Nicotera P (1996) Cytoskeletal breakdown and apoptosis elicited by NO donors in cerebellar granule cells require NMDA receptor activation. J. Neurochem. 67: 2484-2493

29. Leist M, VolbrachtC, Fava E and Nicotera P (1998) 1-Methyl-4-phenylpyridinium induces autocrine excitotoxicity, protease activation, and neuronal apoptosis. Mol. Pharmacol. 54: 789-801

30. Leist M, Volbracht C, Kühnle S, Fava E, Ferrando-May E and Nicotera P (1997) Caspase-mediated apoptosis in neuronal excitotoxicity triggered by nitric oxide. Mol. Med. 3: 750-764

31. Carafoli E (1994) Biogenesis: plasma membrane calcium ATPase: 15 years of work on the purified enzyme. FASEB J. 8: 993-1002

32. Weil M, Jacobson MD, Coles HSR, Davies TJ, Gardner RL, Raff KD and Raff MC (1996) Constitutive expression of the machinery for programmed cell death. J. Cell. Biol. 133: 1053-1059

33. Foletti D, Guerini $D$ and Carafoli E (1995) Subcellular targeting of the endoplasmic reticulum and plasma membrane $\mathrm{Ca} 2+$ pumps: a study using recombinant chimeras. FASEB J. 9: 670-680

34. Zvaritch E, Vellani F, Guerini D and Carafoli E (1995) A signal for endoplasmic reticulum retention located at the carboxyl terminus of the plasma membrane $\mathrm{Ca}(2+)$-ATPase isoform 4Cl. J. Biol. Chem. 270: 2679-2688

35. Smith $C$ and Neher $E$ (1997) Multiple forms of endocytosis in bovine adrenal chromaffin cells. J. Cell. Biol. 139: 885-894

36. Chami M, Gozuacik D, Lagorce D, Brini M, Falson P, Peaucellier G, Pinton P, Lecoeur H, Gougeon ML, le Maire M, Rizzuto R, Brechot $C$ and Paterlini-Brechot P (2001) SERCA1 truncated proteins unable to pump calcium reduce the endoplasmic reticulum calcium concentration and induce apoptosis. J. Cell. Biol. 153: $1301-1314$

37. MarkRJ, Hensley K, Butterfield DA and Mattson MP (1995) Amyloid beta-peptide impairs ion-motive ATPase activities: evidence for a role in loss of neuronal $\mathrm{Ca} 2+$ homeostasis and cell death. J. Neurosci. 15: 6239-6249

38. Oguro K, Nakamura M and Masuzawa T (1995) Histochemical study of $\mathrm{Ca}(2+)$ ATPase activity in ischemic CA1 pyramidal neurons in the gerbil hippocampus. Acta Neuropathol. 90: 448-453

39. FadokVA, de Cathelineau A, Daleke DL, Henson PM and Bratton DL (2001) Loss of phospholipid asymmetry and surface exposure of phosphatidylserine is required for phagocytosis of apoptotic cells by macrophages and fibroblasts. J. Biol. Chem. 276: 1071-1077

40. Witting A, Muller P, Herrmann A, Kettenmann H and Nolte C (2000) Phagocytic clearance of apoptotic neurons by Microglia/Brain macrophages in vitro: involvement of lectin-, integrin-, and phosphatidylserine-mediated recognition. J. Neurochem. 75: 1060-1070

41. Hoeppner DJ, Hengartner MO and Schnabel R (2001) Engulfment genes cooperate with ced-3 to promote cell death in Caenorhabditis elegans. Nature 412: $202-206$ 
42. Reddien PW, Cameron S and Horvitz HR (2001) Phagocytosis promotes programmed cell death in C. elegans. Nature 412: 198-202

43. Hirt UA, Gantner F and Leist M (2000) Phagocytosis of nonapoptotic cells dying by caspase-independent mechanisms. J. Immunol. 164: 6520-6529

44. Hu B, Sonstein J, Christensen PJ, Punturieri A and Curtis JL (2000) Deficient in vitro and in vivo phagocytosis of apoptotic $\mathrm{T}$ cells by resident murine alveolar macrophages. J. Immunol. 165: 2124-2133

45. Scoltock AB, Bortner CD, St J Bird G, Putney Jr. JW and Cidlowski JA (2000) A selective requirement for elevated calcium in DNA degradation, but not early events in anti-Fas-induced apoptosis. J. Biol. Chem. 275: 30586-30596

46. Camandola S, Poli G and Mattson MP (2000) The lipid peroxidation product 4hydroxy-2,3-nonenal increases AP-1- binding activity through caspase activation in neurons. J. Neurochem. 74: 159-168

47. Nath R, Raser KJ, Stafford D, Hajimohammadreza I, Posner A, Allen H, Talanian RV, Yuen P, Gilbertsen RB and Wang KK (1996) Non-erythroid alpha-spectrin breakdown by calpain and interleukin 1 beta-converting-enzyme-like protease(s) in apoptotic cells: contributory roles of both protease families in neuronal apoptosis. Biochem. J. 319: 683-690

48. Hara H, Fink K, Endres M, Friedlander RM, Gagliardini V, Yuan J and Moskowitz M (1997) Attenuation of transient focal cerebral ischemic injury in transgenic mice expressing a mutant ICE inhibitory protein. J. Cereb. Blood Flow Metab. 17: $370-375$

49. Hotchkiss RS, Chang KC, Swanson PE, Tinsley KW, Hui JJ, Klender P, Xanthoudakis S, Roy S, Black C, Grimm E, Aspiotis R, Han Y, Nicholson DW and Karl IE (2000) Caspase inhibitors improve survival in sepsis: a critical role of the Iymphocyte. Nat. Immunol. 1: 496-501

50. Falchetto R, Vorherr T, Brunner J and Carafoli E (1991) The plasma membrane $\mathrm{Ca} 2+$ pump contains a site that interacts with its calmodulin-binding domain. J. Biol. Chem. 266: 2930-2936

51. James P, Vorherr T, Krebs J, Morelli A, Castello G, McCormick DJ, Penniston JT, De Flora A and Carafoli E (1989) Modulation of erythrocyte Ca2+-ATPase by selective calpain cleavage of the calmodulin-binding domain. J. Biol. Chem. 264: $8289-8296$

52. Bursch W, Ellinger A, Gerner C, Frohwein U and Schulte-Hermann R (2000) Programmed cell death (PCD). Apoptosis, autophagic PCD, or others? Ann. NY Acad. Sci. 926: 1-12

53. Nicotera P, McConkey DJ, Jones DP and Orrenius S (1989) ATP stimulates $\mathrm{Ca} 2+$ uptake and increases the free $\mathrm{Ca} 2+$ concentration in isolated rat liver nuclei. Proc. Natl. Acad. Sci. USA 86: 453-457

54. Lanini L, Bachs $O$ and Carafoli $E$ (1992) The calcium pump of the liver nuclear membrane is identical to that of endoplasmic reticulum. J. Biol. Chem. 267: $11548-11552$

55. Jones DP, McConkey DJ, Nicotera P and Orrenius S (1989) Calcium-activated DNA fragmentation in rat liver nuclei. J. Biol. Chem. 264: 6398-6403

56. Enari M, Sakahira H, Yokoyama H, Okawa K, Iwamatsu A and Nagata S (1998)A caspase-activated DNase that degrades DNA during apoptosis, and its inhibitor ICAD. Nature 391: 43-50
57. Carafoli E, Santella L, Branca D and Brini M (2001) Generation, control, and processing of cellular calcium signals. Crit. Rev. Biochem. Mol. Biol. 36: $107-$ 260

58. LinckB, Qiu Z, He Z, Tong Q, Hilgemann DW and Philipson KD (1998) Functional comparison of the three isoforms of the $\mathrm{Na}+/ \mathrm{Ca} 2+$ exchanger (NCX1, NCX2 NCX3). Am. J. Physiol. 274: C415-C423

59. Charriaut-Marlangue C, Aggoun-Zouaoui D, Represa A and Ben-Ari Y (1996) Apoptotic features of selective neuronal death in ischemia, epilepsy and gp I20 toxicity. TINS 19: 109-114

60. Li Y, Sharov VG, Jiang N, Zaloga C, Sabbah HN and Chopp M (1995) Ultrastructural and light microscopic evidence of apoptosis after middle cerebral artery occlusion in the rat. Am. J. Pathol. 146: 1045-1051

61. Gwag BJ, Lobner D, Koh JY, Wie MB and Choi DW (1995) Blockade of glutamate receptors unmasks neuronal apoptosis after oxygen-glucose deprivation in vitro. Neurosci. 68: 615-619

62. Schulz JB, Weller M, Matthews RT, Heneka MT, Groscurth P, Martinou JC Lommatzsch J, von Coelln R, Wullner U, Loschmann PA, Beal MF, Dichgans J and Klockgether $T$ (1998) Extended therapeutic window for caspase inhibition and synergy with MK- 801 in the treatment of cerebral histotoxic hypoxia. Cell Death Differ. 5: 847-857

63. Cohen GM, Sun X-M, Snowden RT, Dinsdale D and Skilleter DN (1992) Key morphological features of apoptosis may occur in the absence of internucleosomal DNA fragmentation. Biochem. J. 286: 331-334

64. Guerini D, Zecca-Mazza A and Carafoli E (2000) Single amino acid mutatons in transmembrane domain 5 confer to the plasma membrane $\mathrm{Ca} 2+$ pump properties typical of the $\mathrm{Ca} 2+$ pump of endo(sarco)plasmic retuculum. J. Biol. Chem. 275: 31361-31368

65. Cockett MI, Bebbington CR and Yarranton GT (1990) High level expression of tissue inhibitor of metalloproteinases in Chinese hamster ovary cells using glutamine synthetase gene amplification. Biotechnology (NY) 8: 662-667

66. Guerini D, Schroder S, Foletti D and Carafoli E (1995) Isolation and characterization of a stable Chinese hamster ovary cell line overexpressing the plasma membrane $\mathrm{Ca}(2+)$-ATPase. J. Biol. Chem. 270: 14643-14650

67. Heim R, Iwata T, Zvaritch E, Adamo HP, Rutishauser B, Strehler EE, Guerini D and Carafoli E (1992) Expression, purification, and properties of the plasma membrane $\mathrm{Ca} 2+$ pump and of its N-terminally truncated $105-\mathrm{kDa}$ fragment. J. Biol. Chem. 267: 24476-24484

68. Adamo HP, Caride AJ and Penniston JT (1992) Use of expression mutants and monoclonal antibodies to map the erythrocyte Ca2+ pump. J. Biol. Chem. 267 $14244-14249$

69. Sarkadi B, Enyedi A, Foldes-Papp Z and Gardos G (1986) Molecular characterization of the in situ red cell membrane calcium pump by limited proteolysis. J. Biol. Chem. 261: 9552-9557 